\title{
Negotiation under the threat of an auction
}

\author{
Nihat Aktas, Eric de Bodt*, and Richard Roll
}

This draft: January 14, 2009

\begin{abstract}
Most gains in takeovers accrue to targets, suggesting the presence of strong competition among acquirers. Yet recent literature documents a seemingly contradictory fact; a large majority of all takeovers occur after one-on-one negotiations. We seek to determine whether the acquirers in such friendly deals are totally insulated from competitive pressures. Realizing that the mere possibility of an open auction might threaten negotiations, we emphasize the role of ex ante competition, the likelihood that rival bidders will appear. Using several proxies, we find that ex ante competition increases the bid premium for directly-negotiated deals. We show also that auction costs reduce the bid premium required by targets in negotiations.
\end{abstract}

JEL classification: G34

Keywords: Merger Negotiation, Ex-ante Competition, Bid Premium

\begin{tabular}{|c|c|c|c|}
\hline & Aktas & de Bodt & Roll \\
\hline Address & $\begin{array}{l}\text { EMLYON Business School } \\
23 \text { av. Guy de Collongue } \\
69130 \text { Ecully } \\
\text { France }\end{array}$ & $\begin{array}{l}\text { Université de Lille } 2 \\
\text { Lille School of Management } \\
1 \text { place Déliot - BP381 } \\
59020 \text { Lille Cédex } \\
\text { France }\end{array}$ & $\begin{array}{l}\text { The Anderson School } \\
\text { UCLA } \\
\text { Los Angeles, CA 90095-1481 } \\
\text { USA }\end{array}$ \\
\hline Voice & $+33-4-7833-7847$ & $+33-3-2090-7477$ & $+1-310-825-6118$ \\
\hline Fax & $+33-4-7833-7928$ & $+33-3-2090-7629$ & $+1-310-206-8404$ \\
\hline E-mail & aktas@em-lyon.com & eric.debodt@univ-lille2.fr & rroll@anderson.ucla.edu \\
\hline
\end{tabular}

*Corresponding author

We are grateful to Marina Balboa, Audra Boone, Espen Eckbo, Robert Hansen, Alexander Kempf, Harold Mulherin, Angel Pardo, Antonio Rubia, Piet Sercu, Karin S. Thorburn, to the participants of the American Finance Association Annual Meeting 2009 (San Francisco), the Core Economic Theory seminar, the French Finance Association Annual Meeting 2008, the KULeuven seminar, the Lille School of Management seminar, the Tuck School of Business research seminar, the University of Cologne CFR seminar and the workshop on mergers at Valencia University for their many comments and suggestions. We thank also Jarrad Harford and Armin Schwienbacher for providing us with the data series on commercial and industrial loan rate spreads and on private buyout funds investments, respectively. All errors and omissions remain ours. Part of this research was done while Aktas was at the Université catholique de Louvain (IAG-Louvain School of Management and Core). 


\section{Negotiation under the threat of an auction}

"The greatest obstacle in an auction is that strategic buyers with reasons to offer higher prices may refuse to participate. ... The mere threat of an auction, however, is often enough to galvanize a strategic buyer into making a good preemptive offer."

Brian O'Hare (partner at Coram Clairfield) Source: Clairfield Review, Third Quarter 2006

\section{Introduction}

Among the many results reported in the merger and acquisition (M\&A) literature, the apparent low level of competition among bidders is particularly puzzling. Betton et al. (2008) report that, out of 35,727 bids for public and private U.S. targets during the period 1980-2005, 33,836 (94.7\%) are single bid contest, most often classified as friendly transactions. The authors also stress that the diffusion of poison pills and other anti-takeovers defenses at the beginning of the 1990s has virtually eliminated hostile takeovers, which represent the most striking form of competition among management teams to obtain or keep control of assets. Boone and Mulherin (2007; 2008a), analyzing a sample of 308 takeovers in the 1990s for which they collect information from the U.S. Securities and Exchange Commission (SEC) show that half of their sample deals are one-on-one negotiations without explicit competition and that bid premiums are not significantly different between singlebidder negotiations and auctions with multiple bidders. If competition exists in the M\&A market, its lack of impact on bid premium is puzzling.

Is the market for corporate control non-competitive? This question is important. Competition among rival bidders to acquire targets promotes efficient allocation of management teams among corporations. Efficient allocation of management teams is probably one of the best ways to protect shareholders and create wealth. Competition is a key ingredient if the market for corporate control is to exert effective external control over incumbent managers. According to Manne (1965, p. 113), "greater capital losses are prevented by the existence of a competitive market for corporate control." 
An absence of competition in the market for corporate control would also raise intriguing questions. Why do the shareholders of target firms not systematically require competitive sale procedures? It is well known that competition increases the expected revenue of the seller. Bulow and Klemperer (1996) show, for example, that, in an English auction, the seller is always better off having one more bidder than engaging in a follow-on bargaining procedure with the winning bidder. If friendly transactions are genuinely free of competition, the high percentage of friendly negotiations in the M\&A market is definitely puzzling. Why do bidders have such low (or negative) cumulative abnormal returns (CARs) while target shareholders profit from large, positive and significant wealth effects (see, e.g., Jensen and Ruback, 1983; Moeller et al., 2004; Betton et al., 2008)? In the absence of competition, this contradicts intuition (and insights provided by auction theory): non-competitive bidders should be able to keep a significant fraction of the wealth creation generated by mergers and acquisitions.

Is the market for corporate control really lacking competition? Or is the M\&A market more competitive than it appears? These are the question that we address in this paper.

To anticipate, we argue that ex ante competition is the underlying explanation for acquirers' bidding behavior. It is the pressure of potential rivals that matters. Though hidden, competitive pressure exists also in supposedly friendly negotiations (even when, ex post, the reported number of bidders is one). Our argument is analogous to the theory of contestable markets (Baumol, 1982). Even when there is only one buyer, that buyer may be forced to act as if there were more. A perfectly contestable market is characterized by absolutely costless entry and exit. In such a market, competitive pressures exerted by the perpetual threat of entry, as well as by the presence of actual rivals, induce competitive behavior. Free entry is a key condition for a market to be perfectly contestable. Similarly, we 
argue that the cost of organizing the auction is an important factor explaining the pressure of ex ante competition.

Adopting a similar depiction of the takeover contest as Betton et al. (forthcoming), we first provide a theoretical analysis of the role of ex ante competition in the M\&A market. The model focuses on friendly deals (negotiations between the parties), which are dominant in number. The acquirer's decision process in friendly deals is represented as a two-stage extensive game with a finite horizon. The first stage is the bargaining stage: the acquirer proposes a bid for the target shares. If the target shareholders accept the proposed bid, the game ends. If the target shareholders rebuff the bid, they organize an auction to sell their shares. This second stage can be either a private-auction process such as those highlighted by Hansen (2001) and Boone and Mulherin (2007) or, mainly for listed targets, the appearance of other potential acquirers. The second stage is modeled as a classic second-price auction.

The target shareholders' decision to accept or rebuff the initial acquirer's bid in the first stage depends on the bid level but also on auction costs in the second stage. These costs include direct costs such as financial intermediaries' fees and commissions, communication and advertising expenses, and indirect costs such as the time delay needed to complete the auction or the uncertainty over the number of bidders and their valuations. While direct costs can be estimated by the acquirer (e.g., by asking an investment banker to provide some estimates), the indirect costs are a function of the target shareholders' urgency to sell and are thus private knowledge. The acquirer's trade-off during the bargaining phase is therefore clear: choosing a high bid increases the probability of concluding the deal without being subject to competitive pressure in the second stage, but it is costly. We solve the game by backward induction to identify the sub-game perfect equilibrium.

This model allows us to explore the impact of competition (the number of bidders in the second stage) on the equilibrium bidding strategy of the first stage acquirer. We find that a 
higher number of rival bidders anticipated in the second stage induces higher bids from the first stage acquirer (during the bargaining phase) and results in lower bidder profits. This provides our main testable hypothesis: the acquirer's bid during the bargaining phase should be an increasing function of ex ante competition (the anticipated number of bidders in the auction stage if the negotiations fail in the first stage). Our second testable implication is that higher expected costs of organizing the auction result in lower bid premium during the bargaining phase.

Strategic actions by acquirers renders the ex-post observed number of bidders a poor proxy for the ex ante competition and suggests the importance of developing better proxies for ex ante competition. In this regard, our argument is close to Fishman's $(1988 ; 1989)$ in the context of jump bidding.

The empirical analysis of ex ante competition on acquirers' bidding behavior in friendly negotiations requires a precise understanding of the procedures used by the involved parties. Following Boone and Mulherin (2007), we develop this key information using the merger background section of the U.S. Securities and Exchanges Commission (SEC) 14A and S-4 filings for mergers and 14D filings for tender offers. The availability of SEC filings limits the sample period to 1994-2006 but allows us to collect several other interesting variables (such as the identity of the initiator and the number of contacted potential bidders in a formal or an informal auction ${ }^{1}$ ). The availability of control variables limits the sample size to approximately 600 transactions, each one "significant" as defined in Masulis et al. (2007). Since our theoretical predictions pertain to the acquirer's bidding behavior, our dependent variable is the bid premium.

\footnotetext{
${ }^{1}$ As in Boone and Mulherin (2007) the auction can be either formal or informal. A formal auction is organized by financial intermediaries at the request of the target and the bidding evolves in structured way. An informal auction is a process wherein the target or its financial advisors contact potential acquirers in a less structured way.
} 
We introduce several proxies for ex ante competition. Using an algorithm suggested in Harford (2005), we identify M\&A waves at the industry level. This provides our first proxy for ex ante competition: an M\&A wave dummy variable, which takes the value one when the transaction is announced during an M\&A wave. The rationale is that competition for targets is stronger during M\&A waves. To test whether the results are affected by a forward looking bias, we also use the probability of being in an M\&A wave estimated with a logit model based on the M\&A wave predictors suggested in Harford (2005). Our second proxy for ex ante competition is the lagged deal frequency (the number of deals in the industry divided by the number of firms in the industry during either the last three months or the last six months). The rationale is again that more competition leads to more deals. We lag the deal frequency to circumvent potential endogeneity among the competition to acquire targets in an industry, the attractiveness of targets in the industry and the bidding behavior of acquirers. Our third proxy of ex ante competition is a measure of the private buyout funds activities. The investments of buyout funds grown dramatically during the last decade (see Boone and Mulherin, 2008b) and the presence of such funds could represent tough competition for targets. Our last proxy is a dummy variable for recessions identified by the National Bureau of Economic Research (NBER). During recessions, competition among bidders might be smaller.

In our model, the eagerness for the target shareholders' to sell is an important determinant of auction costs. To proxy for this eagerness, we use the target's debt ratio. The rationale is that a high level of debt represents pressure on the target to negotiate quickly. In our sample, the debt ratio is positively correlated with the target's market to book ratio and the target's return on assets and, therefore, is not an indication of poor target quality. Moreover, we control in the multivariate analysis for the quality of target using the target Tobin's $q$ ratio. 
From the econometric viewpoint, two potential pitfalls within our multivariate analyses are the inclusion of generated regressors and self-selection. We control the first issue by using the Murphy and Topel Theorem [see Greene (2008, p. 509)] to adjust standard errors. To offset self-selection, we use the classic Heckman approach (Heckman, 1979) to model the choice of selling procedure (negotiation versus auction).

The results generally confirm the impact of ex ante competition on the bidding behavior of acquirers, in particular for negotiated transactions; more potential competitors are associated with higher bids. The only exception is for the wave dummy proxy of ex ante competition; which fails to deliver statistically significant results.

We also find that: (i) targets with more debt obtain lower premiums in negotiations. This result confirms that auction costs affect bid premiums in negotiations; (ii) the effect of ex ante competition on the bidding behavior of acquirers is weaker when estimated with a mixed sample of negotiated and auctioned (formal or informal) transactions; (iii) the deal initiator role (acquirer or target) is a primary determinant of the selling procedure. Target-initiated deals are most often auctions while bidder-initiated deals are most often negotiations. This is consistent with the idea that targets try to stimulate competition while acquirers seek to avoid it.

We provide also various robustness checks. Among them, we test whether our proxies of ex ante competition are positively correlated with deal synergies. They are not. This rules out an alternative explanation (that they are actually proxying for the merger's wealth creation).

These results, taken together, help to solve the puzzling questions raised by the apparent (almost) absence of ex-post observable competition in the M\&A market. Competition need not be observed ex-post to play a crucial role. The mere threat of rival offers is powerful enough to increase bids. This helps explain why targets do not systematically resort to auctions when they are solicited by single bidders. Auctions are costly and time-consuming. 
In a sample mixing auctions and negotiations, the ex-post observed number of bidders turns out to be a poor proxy for competition Even when the there is only a single bidder (the definition of a negotiation) the bid premium can be in high when there is a competitive environment during the negotiations. This contributes to explaining why previous studies did not uncover a significant relation among ex-post measures of competition, bid premiums and acquirer CARs.

Our results complement results in previous studies (see, e.g., Mitchell and Lehn, 1990; Masulis et al., 2007) that the M\&A market is an effective external corporate governance mechanism (competition being a necessary condition for this mechanism to play its role). Our results are also consistent with the idea that the bid premium can be used by acquirers to deter competition; this constitutes indirect empirical support for jump bidding models such as Fishman $(1988 ; 1989)$. The third stream of literature related to our work involves bargaining and auction models in corporate finance. By analyzing the interconnection between a bargaining phase and an auction phase within an extensive game, like Betton et al. (forthcoming), our model illustrates the spectrum of potential applications of such theory in corporate finance.

This paper is organized as follows. Section 2 first summarizes the known facts about the relation between competition, acquirer bidding behavior and $\mathrm{M} \& \mathrm{~A}$ wealth effects for the involved parties. It goes on to formalize the relation between ex ante competition and acquirer bidding behavior in the framework of negotiated deals. Section 3 is devoted to the related empirical analysis. Section 4 provides some complementary robustness checks. Section 5 concludes. 


\section{Competition and the market for corporate control}

\subsection{Stylized facts}

Andrade et al. (2001), studying a U.S. sample of deals between listed companies in the period 1973-1998, show that the average number of bidders per deal is around 1.1. In Moeller et al. (2007) only $4.19 \%$ of the 4,322 deals announced by U.S. firms in the period 1980-2002 involved competition by rival bidders. Betton et al. (2008), focusing on 35,727 bids during the period $1980-2005$, find that $94.7 \%$ are single bids and $1.8 \%$ are multiple bids by a single bidder. Only $3.4 \%$ are multiple bids with rival bidders. Overall, these numbers depict a very low level of ex-post observable competition.

Observable competition was somewhat higher for tender offers in the 1970s and 1980s, when hostile bids were more frequent. Indeed, hostility itself indicates competition between management teams seeking to control of the same target assets [in the spirit of the Manne (1965) concept of the market for corporate control.] Betton and Eckbo (2000) study takeover contests in tender offers by U.S. firms over the period 1971-1990. In a sample of 1,353 initial bids, 508 cases involved multiple-bid contests, and out of these, 214 cases were challenged by rival bidders immediately after the first bid. In other words, $845(62.4 \%)$ initial bids were not challenged by rival companies. So even during this specific period, expost competition is observable in only a minority of cases. Moreover, since the beginning of the nineties, with the diffusion of poison pills and other powerful anti-takeover mechanisms, hostile transactions have become rare (Betton et al., 2008).

Private takeovers provide other interesting evidence. Boone and Mulherin (2008a) argue that the number of bidders is a noisy and incomplete measure of takeover competition. Using merger documents from the U.S. SEC, the authors build sophisticated proxies for competition based on how many potential bidders were contacted in private sales process and how many actually submitted bids. These authors analyze 308 takeovers in the 1990s. They report that 
for 145 transactions ( $47 \%$ of the sample), the sale procedure was a private auction among multiple bidders. For the remaining cases, there was a direct negotiation with only one bidder.

For private auctions, on average, 13.81 potential buyers were contacted, 5.77 completed a confidentiality agreement, 1.51 submitted a private written offer and 1.23 publicly announced a formal bid. ${ }^{2}$ From private takeovers, then, two main conclusions appear to be (1) auctions take place in fewer than half of the transactions and (2) only a small number of potential buyers actually submit a bid. Such data reinforce the impression that competition is, at best, quite low in the M\&A market. Boone and Mulherin (2007, 2008a) also provide results on the relations among competition, bid premiums, acquirer and target CARs and transaction procedures. Their main conclusions are that (i) target CARs and bid premiums are not significantly different between negotiations and auctions, (ii) competition (based on information about the private takeover process) do not affect acquirers' CARs and (iii) target intangibles, the mode of payment and the presence of investment banks are significant determinants transactions procedures.

To conclude this literature review, it is worthwhile returning to one of the most wellknown stylized facts about the M\&A market: acquirers experience low (if not negative) CARs when announcing deals while target shareholders capture most of the wealth creation (and wealth transfer, if any) (see, e.g., Jensen and Ruback, 1983; Moeller et al., 2004). If competition is low, this fact contradicts auction theory (see Dasgupta and Hansen, 2007). For example, in second price auction with $N$ risk neutral symmetric bidders and private values, it is well known that a weakly dominant strategy is to bid the assessed value. Assuming that

\footnotetext{
${ }^{2}$ In considering these figures, it is worthwhile to keep in mind Hansen's (2001) observation that the number of bidders is often voluntarily limited in private takeovers. The author provides a rationale; viz., if proprietary information about the target were diffused too widely, the target's value could be diminished. Evidently, there is a trade-off between a large number of competitive bidders to stimulate competition and the diffusion of sensitive information.
} 
valuations follow a uniform distribution bounded between 0 and 1 , the seller's expected revenue is $(N-\mathbf{1}) /(N+\mathbf{1})$ (see Appendix A). This means that with two bidders, the seller's expected revenue is $1 / 3$. This represents $1 / 2$ of the expected winning bidder's valuation. With five bidders (far more than is usually observed in M\&As), the seller's expected revenue is $2 / 3$. This amounts to $4 / 5$ of the expected winning-bidder valuation. Hence, the proportion of value kept by the winning bidder (the ex-post observed acquirer) should not be close to zero unless the number of bidders is unusually large. From an auction theory perspective, only a highly competitive market for corporate control would explain the low CARs of acquirers. $^{3}$

\subsection{Negotiation and ex ante competition}

In this section, we explore the relation between ex ante competition and acquirer bidding behavior when there are only bilateral negotiations (and only a single observed bidder). The focus is on negotiations for two reasons: (i) they represent half of all cases and (ii) only ex ante competition is possible (there is no ex-post competition). The framework is similar to Betton et al. (forthcoming). A related two-stage representation of the takeover contest can also be found in Burkart et al. (2000).

\subsubsection{Model setup}

The model is designed to reflect the essential features of a typical situation: a public firm is contacted by a potential acquirer, and negotiations begin. At the conclusion of negotiations, the initial prospective acquirer makes an acquisition offer $b_{1}$. If the target refuses this initial offer, rival bidders appear (the failed negotiation alerts them to the investment opportunity). A takeover battle ensues, with multiple bidders. The initial suitor makes another offer $b_{2}$ during this second stage. The game ends with the sale of the target.

\footnotetext{
${ }^{3}$ The free-rider argument of Grossman and Hart (1980) provides an alternative explanation of why most wealth from M\&A deals accrues to target shareholders. However, it assumes strictly atomistic shareholding.
} 
Ex-post, when the first-stage negotiations are successful, the deal is characterized as "friendly" in the financial press.

Such a model is general enough to describe other situations. For example, the sale of a firm may be at the request of its shareholders (e.g., family shareholders), who contact a financial intermediary. A potential acquiring firm is found, and negotiations ensue. Because the shareholders really want to sell, the financial intermediary has a mandate to organize a private auction among multiple potential bidders if the initial negotiations break down. This corresponds to some of the situations described by Boone and Mulherin (2007). The essential nature of these situations is that there is a two-stage takeover process: private negotiations first and then, if the negotiations fail, a competitive procedure.

We model this situation using an extensive game with perfect information: each player knows the decisions taken previously by the other players. In the first stage, however, information is asymmetric. A second stage auction implies additional direct costs (such as financial intermediary fees and commissions, communication and advertising expenses, etc.) and indirect costs (such as the time delay needed to complete the auction or uncertainty about the number of bidders and their valuations). The magnitude of indirect costs perceived by target shareholders depends on their eagerness to sell, which is known only by them. Therefore, while the direct costs are common knowledge, the indirect costs are private knowledge of the target shareholders. We denote auction costs $c .{ }^{4}$ These costs play, in our model, the same role as the costs of participating in a sale process in Bulow and Klemperer (2007), where the authors analyze the conditions under which auctions are the most efficient

\footnotetext{
${ }^{4}$ Auction costs are, in our model, the key factor driving the bargaining power of the parties during the negotiation. Ahern (2009) provides an empirical exploration of the relation between the bargaining power of the merging parties and the division of merger gains. The author uses industry dependence measures to proxy for bargaining power.
} 
selling mechanism. Note also that we assume [as does Samuelson (1984)] that the target shareholders have no way of credibly communicating the cost of organizing an auction.

In the first stage (the initial negotiation), the acquirer is assumed to make a single offer. Not only does this assumption simplify the analysis (we do not have to model the intricacies of the negotiation procedure) but moreover, Samuelson (1984) has shown that it corresponds to the optimal behavior for a buyer bargaining with asymmetric information. We model the second stage as a second-price auction. In our setup, by the revenue equivalence theorem (see Milgrom, 2004), equilibrium strategies and expected payoffs are equivalent to those obtained in an English auction and in a first-price auction.

When there is a takeover battle, we assume that the rejected first stage bid is a lower bound on the minimum price at which the target shareholders agree to sell their shares (the seller's reserve price).$^{5}$ This makes sense as, by refusing the bid of the initial acquirer, the target shareholders reveal some private information to outside investors. Public investors update their valuations and a new market price emerges for the target firm. This market price becomes the natural lower bound for acquirers wishing to enter the takeover battle in the second stage.

The tradeoffs in the first stage are clear. By increasing the first-stage bid, the acquirer increases the probability that the target will accept the offer but also obviously increase the acquisition cost. Target shareholders compare the immediate and certain bid against an expected sale price after a takeover battle less the associated cost.

\footnotetext{
${ }^{5}$ Note that this reserve price is not generally the optimal reserve price for the seller (see Riley and Samuelson, 1981; Myerson, 1981). Assuming that target shareholders choose the optimal reserve price raises the issue of ex-post commitment [see Dasgupta and Hansen (2007), Section 4.2.2, for a discussion of this point.]
} 


\subsubsection{Additional assumptions and notations}

We assume risk neutrality. $v_{1}$ denotes the target valuation by the initial acquirer and $v_{i}$, the valuation of a given acquirer $i$. Synergies are private to the acquirer. We assume $v_{i}$ to be strictly increasing in synergies. Rivals during the second-stage takeover battle are referred to as $i=2 \ldots N^{6}$. The distribution of $v_{i}$ is $F($.$) and is common knowledge. v_{(i)}$ denotes the order statistic of $v_{i}$ for the $N-1$ rivals. So, $v_{(1)}$ is the maximum of $\left(v_{2}, \ldots . v_{N}\right)$.

We assume that the initial acquirer (whose valuation is $v_{l}$ ) is a high-value bidder: at most one rival firm has a higher valuation. This means, in our notation, that $v_{1} \geq v_{(2)}$. This assumption simplifies the analysis, in particular at Stage 2, and relaxing it does not change our results qualitatively. Moreover, this initial high-value bidder assumption captures one of the empirical features of takeover battles: the first mover frequently wins the competition. For example, Betton and Eckbo (2000) report, for a sample of 1,353 tender offers for the period 1971-1990, that the initial bidder won the contest in 864 (over 63\%) of the cases, and a rival bidder in only 198 (less than 15\%) of the cases. Comparable evidence is reported in Betton et al. (2008).

We denote by $\Pi_{j}^{k}$ the profit of player $j$ at stage $k ; j$ is $\epsilon$ \{acquirer, target $\}$, and $k$ is $\epsilon\{1,2\}$. $p_{j}$ is the price at stage $j . \quad c$ has the atomless distribution $K($.$) in the eyes of the acquirer$ (information is asymmetric, as mentioned in Section 2.2.1), with an upper bound secondstage takeover battle. Finally, we denote by $v_{T}$ the stand-alone value of the target firm in the eyes of its shareholders. We provide in Appendix B a formal description of the game.

\footnotetext{
${ }^{6}$ We assume that the number of rivals is exogenously determined. Hansen (2001) reports the existence of different devices that targets can use to stimulate (or to limit) the entry of additional bidders in firm auctions. One could take account of these devices by including investments made by targets to stimulate the entry of more bidders as part of auction organizing costs. Thus, $c$ would become a decision variable for the target. Such an extension of the model is possible, albeit complex, and it simply reinforces the pressure that targets can put on initial acquirers during negotiations.
} 


\subsubsection{Equilibrium analysis}

We adopt the sub-game perfect equilibrium concept to study the outcome of the game, and restrict our analysis to pure strategies. As we are dealing with a finite-horizon game, backward induction is used to identify the equilibrium.

Second-stage analysis, the takeover battle. We model the takeover battle as a secondprice auction with a reserve price set to the rejected first-stage negotiation offer $b_{1}$. In our independent private-value setting, thanks to Vickrey's (1961) seminal contribution, secondprice auctions with reserve prices are known to be revenue equivalent to English auctions with reserve prices (see Matthews, 1995; Milgrom, 2004). As shown in Table 1, there are three possible outcomes at this second stage:

- Case $1-v_{(1)} \leq b_{1}$ : the maximum valuation of rivals is below the target shareholders' reserve price (the rejected offer in the first stage). Target shareholders then sell their shares to the initial acquirer at price $b_{1}$ (the reserve price plays the role of the second best bid as in second-price auctions with reserve prices). The target shareholders profit is $\Pi_{2}^{\text {Target }}=b_{1}-v_{T}$ -c. The initial acquirer's profit is $\Pi_{2}^{\text {Acquirer }}=v_{1}-b_{1}$. We denote by $\varphi_{1}$ the probability of the occurrence of Case 1.

- Case $2-b_{1}<v_{(1)} \leq v_{1}$ : the maximum valuation of rival acquirers is above the target shareholders' reserve price $b_{1}$ but below the initial acquirer's valuation $v_{1}$. So, the initial bidder wins the auction and pays $\tilde{v}_{(1)}$, the second-best offer. Note that, at this stage, $\tilde{v}_{(1)}$ is a random variable. The target shareholders profit is $\Pi_{2}^{\text {Target }}=\tilde{v}_{(1)}-v_{T}-c$. The initial acquirer's profit is $\Pi_{2}{ }^{\text {Acquirer }}=v_{1}-\tilde{v}_{(1)}$. We denote by $\varphi_{2}$ the probability of the occurrence of

\section{Case 2.}

- Case $3-v_{(1)}>v_{1}$ : the maximum valuation of rivals $v_{(1)}$ is higher than the initial acquirer's valuation $v_{l}$. The rival wins the auction and pays $v_{l}$. The target shareholders profit 
is $\Pi_{2}^{\text {Target }}=v_{1}-v_{T}-c$. The initial acquirer fails to acquire the target and so makes no profit. We denote by $\varphi_{3}$ the probability of the occurrence of Case 3.

\section{[Insert Table 1 About Here]}

$\varphi_{1}$ is the probability that the maximum valuation of the $N-1$ rivals will be below $b_{1}$. The probability that a given rival valuation will be below $b_{1}$ is $F\left(b_{1}\right)$. Under the assumption that the private valuations are independent with a cumulative density function of $F($.$) , the$ probability that the $N-1$ rivals' valuations will all be below $b_{1}$, is $F\left(b_{1}\right)^{N-1}$. We follow the same argument to obtain $\varphi_{2}$ and $\varphi_{3}$. So, the probability of Cases 1,2 and 3 arising are respectively:

Case 1: $\varphi_{1}=F\left(b_{1}\right)^{N-1}$;

Case 2: $\varphi_{2}=F\left(v_{1}\right)^{N-1}-F\left(b_{1}\right)^{N-1}$;

Case 3: $\varphi_{3}=1-F\left(v_{1}\right)^{N-1}$.

Note that, by definition, $\varphi_{1}+\varphi_{2}+\varphi_{3}=1$ and that, as we are in a second-price auction, by the revelation principle, the dominant strategy of acquirers (either the initial acquirer or its rivals) is to bid their own valuation.

The expected price at this Stage 2 takeover battle is the average price at each possible outcome, weighted by the corresponding probability:

$$
E\left(p_{2}\right)=\varphi_{1} b_{1}+\varphi_{2} E\left(\tilde{v}_{(1)} \mid \tilde{v}_{(1)}>b_{1}, \tilde{v}_{(1)} \leq v_{1}\right)+\varphi_{3} v_{1}
$$

The only unknown term in Eq. (4) is $E\left(\tilde{v}_{(1)} \mid \tilde{v}_{(1)}>b_{1}, \tilde{v}_{(1)} \leq v_{1}\right)$. Using Eq. (1) to (3), this conditional expectation is:

$$
E\left(\tilde{v}_{(1)} \mid \tilde{v}_{(1)}>b_{1}, \tilde{v}_{(1)} \leq v_{1}\right)=\int_{b_{1}}^{v_{1}} v \frac{(N-1) F(v)^{N-2} f(f)}{F\left(v_{1}\right)^{N-1}-F\left(b_{1}\right)^{N-1}} d v
$$


Combining Eq. (1) to (5), the expected price of the takeover battle can be rewritten as:

$$
E\left(p_{2}\right)=F\left(b_{1}\right)^{N-1} b_{1}+\int_{b_{1}}^{v_{1}} v(N-1) F(v)^{N-2} f(v) d v+\left(1-F\left(v_{1}\right)^{N-1}\right) v_{1}
$$

Note that,

- $\quad(N-1) F(v)^{N-2} f(v)$ is the density of the rivals' best valuations.

- A direct investigation of Eq. (6) shows that $E\left(p_{2}\right) \geq b_{1} \cdot \quad E\left(p_{2}\right)-b_{1}$ equals $\left(1-F\left(b_{1}\right)^{N-1}\right)\left(v_{1}-b_{1}\right)+\int_{b_{1}}^{v_{1}} v(N-1) F(v)^{N-2} f(v) d v$. By the participation constraint, we see that $v_{1} \geq b_{1} \cdot\left(1-F\left(b_{1}\right)^{N-1}\right)$, being a probability, is positive. The same holds for $F(v)$ and $f(v)$. Note finally that, by definition, $b_{1}$ and $v_{1}$ are also positive. Therefore, the initial acquirer's firststage offer $b_{1}$ is a lower bound of the expected price at Stage 2. This is reminiscent of Bulow and Klemperer's (1996) result: competitive procedures always increase the expected revenue of the seller, compared to direct negotiation. In our model, the target shareholders' tradeoff arises from the costs of letting the takeover battle take place.

- $\partial E\left(p_{2}\right) / \partial b_{1}=F\left(b_{1}\right)^{N-1} \geq 0$ : an increase in the negotiation phase offer $b_{1}$ increases the takeover battle's expected payment, but the greater the competition in the second-stage takeover battle (the larger $N$ ), the lower is this effect. Competition increases indeed the probability that at least one rival will have a valuation above $b_{1}$.

From Eq. (A.6) we obtain the expected profit of the target shareholders at Stage 2 as:

$$
E\left(\Pi_{2}^{\text {Target }}\right)=E\left(p_{2}\right)-v_{T}-c
$$

The initial acquirer's expected profit at the end of the takeover battle is the average profit at each possible outcome weighted by the corresponding probabilities. Using the outcome profits reported in Table 1, the probabilities of each outcome from Eq. (1) to (3) and the conditional expectation of the highest rival valuation given in Eq. (5), we obtain:

$$
E\left(\Pi_{2}^{\text {Acquirer }}\left(v_{1}\right)\right)=F\left(b_{1}\right)^{N-1}\left(v_{1}-b_{1}\right)+\left(F\left(v_{1}\right)^{N-1}-F\left(b_{1}\right)^{N-1}\right)\left(v_{1}-E\left(\tilde{v}_{(1)} \mid \tilde{v}_{(1)}>b_{1}, \tilde{v}_{(1)} \leq v_{1}\right)\right) .
$$


The first part of this expression corresponds to the profit when the rival maximum valuation is below the initial acquirer's bid at the negotiation phase; the second part corresponds to the profit if the rival maximum valuation is above the initial acquirer's bid at the negotiation phase, but below the initial acquirer's valuation. These profits are weighted by the probabilities of their occurrence. Note that $\partial E\left(\Pi_{2}^{\text {Acquirer }}\left(v_{1}\right)\right) / \partial b_{1}=-F\left(b_{1}\right)^{N-1} \leq 0$ : an increase in the first-stage negotiation offer reduces the initial acquirer's second-stage expected profit by the exact amount of the increase in the second-stage takeover battle expected price (see Eq. (6)).

First-stage analysis, the negotiation. Having derived the expressions for the expected profit of the target shareholders and the initial acquirer in the second-stage takeover battle, we can now turn to the analysis of the first-stage negotiation phase. It is worth first noting that in Eq. (6) and (8), $b_{1}$, the initial acquirer's first-stage offer, appears in the term $F\left(b_{1}\right)^{N-1}$. Unless $N=2$ and $F($.$) is linear (uniform distribution), there is therefore no hope of deriving a$ closed-form formula. Stating the target shareholders' and the initial acquirer's decision problems and expected profits at this first stage negotiation is, however, enough for us to study the role of competition and of the cost of organizing the auction.

The target decision problem during the negotiation phase can be expressed as:

$$
\operatorname{Max}_{x \in\{0,1\}} x\left(b_{1}-v_{T}\right)+(1-x) E\left(\Pi_{2}^{\text {Target }}\right)
$$

where $x$ is a binary variable taking the value 1 if accepted and 0 if refused. Using Eq. (A.7) and denoting the optimal decision as $x^{*}$, the target shareholders' expected profit is:

$$
E\left(\Pi_{1}^{\text {Target }}\right)=x^{*}\left(b_{1}-v_{T}\right)+\left(1-x^{*}\right)\left[E\left(p_{2}\right)-v_{T}-c\right] .
$$

The target shareholders will reject the initial acquirer offer if $\left(b_{1}-v_{T}\right) \leq E\left(\Pi_{2}^{\text {Target }}\right)$, this is to say if $c \leq E\left(p_{2}\right)-b_{1}$. This happens with probability $K\left(E\left(p_{2}\right)-b_{1}\right)$ in the eyes of the initial bidder. As expected, the higher the expected price at Stage 2, the higher the probability that 
the initial acquirer's offer is rejected. Increasing the first stage negotiation bid $b_{1}$ increases the probability of acceptance.

The initial acquirer's decision problem at this negotiation phase is

$$
\underset{b_{1}}{\operatorname{Max}}\left(1-K\left(E\left(p_{2}\right)-b_{1}\right)\right)\left(v_{1}-b_{1}\right)+\left(K\left(E\left(p_{2}\right)-b_{1}\right)\right) E\left(\Pi_{2}^{\text {Acquirer }}\left(v_{1}\right)\right)
$$

and the expected payoff of the initial acquirer is given by

$$
E\left(\Pi_{1}^{\text {Acqiorer }}\left(v_{1}\right)\right)=\left(1-K\left(E\left(p_{2}\right)-b_{1}^{*}\right)\right)\left(v_{1}-b_{1}^{*}\right)+\left(K\left(E\left(p_{2}\right)-b_{1}^{*}\right)\right) E\left(\Pi_{2}^{\text {Acquirer }}\left(v_{1}\right)\right) .
$$

It can be shown $b_{1}{ }^{*}$ exists, and the conditions under which it is unique can be established. ${ }^{7}$

\subsubsection{Bid premium, ex ante competition and auction costs}

The model developed in the preceding sub-sections allows us to study (i) the effect of competition in the second-stage takeover battle (here captured by $N-1$, the number of rivals in the second stage) and (ii) the effect of auction costs $c$ on the equilibrium bid $b_{1}^{*}$ that will emerge from the negotiation phase. This will allow us to derive the two propositions that we test in Section 3. We start by analyzing the effects of competition on the Stage 2 takeoverbattle equilibrium outcome. We then return to the Stage 1 negotiation phase.

The role of competition in the takeover battle. Central to the analysis of competition the takeover equilibrium is the effect of the number of rivals on the expected price in the second stage, i.e., the effect of $N-1$ on $E\left(p_{2}\right)$. Using Eq. (6), it can be shown that $E\left(p_{2}\right)$ is increasing in $N-1 .^{8}$ Since the target shareholders' expected profit is $E\left(\Pi_{2}^{\text {Target }}\right)=E\left(p_{2}\right)-v_{T}-c$ (see Eq. (7)), an increase in $N-1$ leads to an increase in $E\left(\Pi_{2}^{\text {Target }}\right)$.

As the initial acquirer's expected profit $E\left(\Pi_{2}^{\text {Acquirer }}\right)$ is by definition the probability of winning the takeover battle times the acquirer's valuation $v_{1}$ minus the expected payment, $E\left(\Pi_{2}^{\text {Acquirer }}\right)$ is decreasing in $N-1$.

\footnotetext{
${ }^{7}$ Proofs are available upon request from the authors.

${ }^{8}$ Proofs are available upon request from the authors.
} 
The role of ex ante competition in the negotiation. It can be shown that the expected initial acquirer payoff in the first stage negotiation $E\left(\Pi_{1}^{\text {Acquirer }}\right)$ satisfies the strict singlecrossing difference condition. ${ }^{9}$ By the monotonic selection theorem (Milgrom (2004, p. 102)), $b_{1}^{*}$, the optimal offer by the initial bidder during the negotiation is a non-decreasing function of $N-1$, the number of rivals. This leads to our first proposition: ${ }^{10}$

Proposition 1. An increase in the number $N-1$ of rivals in the second-stage takeover battle increases the equilibrium initial acquirer offer $b_{1}^{*}$ during the negotiation phase.

Auction costs. The sub-game perfect equilibrium is determined by auction costs, $c$. If $c<E\left(p_{2}\right)-b_{1}$ the sub-game perfect equilibrium is $b_{1}^{*}$, the optimal bid at the negotiation stage and refusal is the rational choice of the target shareholders. $v_{l}$ is the dominant bidding strategy for the initial acquirer during the second stage takeover battle. If $c>E\left(p_{2}\right)-b_{1}$, the sub-game perfect equilibrium is defined by $b_{1}{ }^{*}$, acceptance by the target, and $v_{1}$ (even if the takeover battle does not take place). If $c=E\left(p_{2}\right)-b_{1}$ there are two sub-game perfect equilibria, both of which are potential solutions of the game.

The expected profit of the initial acquirer at the first stage negotiation, given in Eq. (12), is a weighted sum of the profits given negotiation success and failure, the latter followed by an auction. The weights are the probabilities of initial offer acceptance and refusal, respectively $\left(1-K\left(E\left(p_{2}\right)-b_{1}^{*}\right)\right)$ and $\left(K\left(E\left(p_{2}\right)-b_{1}^{*}\right)\right) . K($.$) is the distribution of auction costs$ as estimated by the initial acquirer. An increase in auction costs [a shift of $K($.$) to the right],$ puts more weight on the initial acquirer's profit for negotiation success $\left[\left(v_{1}-b_{1}^{*}\right)\right]$ and correspondingly less weight on profit given negotiation failure $\left[E\left(\Pi_{2}^{\text {Acquirer }}\left(v_{1}\right)\right)\right]$. As

\footnotetext{
${ }^{9}$ Proofs are available upon request from the authors.

${ }^{10}$ We explore in Appendix $\mathrm{C}$ the consequences of an increase in the number of rivals in the second-stage takeover battle, the probability of negotiation failure and the initial acquirer and target expected profits.
} 
$\partial\left(v_{1}-b_{1}^{*}\right) / \partial b_{1}^{*}=-1 \leq-F\left(b_{1}^{*}\right)^{N-1}=\partial E\left(\Pi_{2}^{\text {Acquirer }}\left(v_{1}\right)\right) / \partial b_{1}^{*}$, we conclude that an increase in auction costs leads to a decrease in $b_{1}^{*}$. This leads to our second proposition:

Proposition 2. An increase in auction costs decreases the equilibrium initial acquirer offer $b_{1}^{*}$ during the negotiation phase.

In the sequel to the paper, we propose an empirical test of the two propositions derived in this section.

\section{Empirical evidence}

This section first describes and justifies the M\&A sample and then discusses the dependent, independent and control variables. Next, strategies are formulated to overcome various econometric difficulties. Finally empirical findings are reported.

\subsection{Sample description}

The sample of acquisitions is extracted from the Securities Data Corporation's (SDC) U.S. Mergers and Acquisitions database. Because we require information from the SEC filings, our extraction period is from January 1, 1994 to December 31, 2006 (SEC filings are publicly available through the EDGAR system of the SEC beginning on the first of these dates). We identify 2,677 completed deals that meet the following criteria:

1. Both the target and the bidder are listed U.S. firms. SEC filings are available only for listed firms. Moreover, potential determinants of the bid premium, such as the target run-up (Schwert, 1996) or the ratio of acquirer to target Tobin's $q$ (Servaes, 1991) are computed from market information.

2. The acquisition is significant as in Masulis et al. (2007). More precisely, the acquirer increases shareholdings in the target from less than $50 \%$ before the announcement to $100 \%$ afterward and the deal value disclosed in SDC is above \$1 million and 
represents more than $1 \%$ of the acquirer's market value measured 40 days before the announcement date.

3. The bid premium in percentage (computed using the target market price four weeks prior to the announcement date) is available in the SDC database.

We require moreover that (i) the Gompers, Ishii, and Metrick (2003) index (GIM index) is available for the acquirer (to control for corporate governance issues) and (ii) the IBES database provides financial analysts' forecasts for acquirer long term earnings growth (to control for uncertainty about acquirer value (Moeller et al., 2007). These two additional criteria reduce the sample size to 1,076 . The computation of Tobin's $q$ (and other financial ratios) requires data from Compustat database. Sixty-nine more deals are lost at this step. For the 1,007 remaining deals, 754 SEC filings are identifiable from the EDGAR system of the SEC (14A and S-4 filings for mergers and 14D filings for tender offers). Following Boone and Mulherin (2007), we use the merger background section of the SEC filings to classify the selling procedure as a negotiation or an auction. It is an auction if multiple bidders are mentioned and a negotiation when there is a single buyer. Using the same SEC filings, we also tried to ascertain whether initiator was the target or the winning bidder. ${ }^{11} \mathrm{We}$ were able to determine the selling procedure and the initiator for 591 transactions. Out of these 591 transactions, 286 are one-on-one negotiations, and 250 deals are target-initiated.

Table 2 provides the sample distribution by year. Four samples are analyzed: $S D C$ is the sample comprising the 2,667 acquisitions listed in SDC and obtained using the selection criteria described above; SEC Filings is the sub-sample of deals with an identifiable selling procedure; Auction is the sub-sample with multiple bidders and Negotiation is the sub-sample with a single buyer.

\footnotetext{
${ }^{11}$ When it is not possible to infer the party initiating the deal between the winning bidder and the target from the available SEC filings, we assume that the winning bidder is the initiator.
} 
The SDC sample exhibits a peak in the number of transactions between 1997 and 2000, which is consistent with the well documented "friendly" M\&A wave of the end of the nineties (Betton et al., 2008). The Negotiation, Auction, SDC and SEC filings samples display similar patterns from year to year except for a moderate increase in negotiations relative to auctions during the years 1998-1999, which corresponds to the peak in the M\&A market activity.

\section{[Insert Table 2 About Here]}

Table 3 reports descriptive statistics about firms and deals in the samples. Panel A focuses on firm size and allows a direct comparison to the Boone and Mulherin (2007) sample. Panel B reports deal characteristics. Panel C and D are dedicated to target and acquirer characteristics, respectively. The final column of the table presents the $p$-value of a means test of the null that the Auction and Negotiation sub-samples are equal. The variables included in Panels C and D are potential determinants of either the bid premium or the selling procedure choice and will be used in our later multivariate analyses. Variable definitions are in Appendix D. All financial ratios are winsorized at $1 \%$ and $99 \%$ to limit the influence of outliers. For industry related variables, we use the Fama-French 49 industry classification scheme. SIC industry codes are obtained from CRSP database and then converted using the table provided by Kenneth French on his internet site. ${ }^{12}$

\section{[Insert Table 3 About Here]}

Panel A shows that the sub-samples constructed using the SEC filings focus on larger acquirers and targets than the full SDC sample. This is not surprising since the selection criteria include such restrictive requirements as the availability of the GIM index. [Gompers et al. (2003) emphasize that firms in the Investor Responsibility Research Center (IRRC)

\footnotetext{
${ }^{12}$ http://mba.tuck.dartmouth.edu/pages/faculty/ken.french/data_library.html.
} 
database are large companies.] The large difference between the mean (59\%) and the median $(15 \%)$ in the relative size of targets to acquirers for the $S D C$ sample highlights the presence of many small acquirers that are excluded from the other samples.

Comparing the Auction and Negotiation sub-samples reveals that auctioned targets are significantly smaller firms and are acquired by significantly smaller buyers. There is also a significant difference in relative size: targets are bigger relative to their buyers when there are negotiations only. Boone and Mulherin (2007) report similar evidence with respect to target and acquirer size. Acquirers are however smaller in their sample $(\$ 3.41$ billion median size versus $\$ 4.97$ billion in our sample) while targets are bigger ( $\$ 0.69$ billion median size versus $\$ 0.41$ billion in our sample). The difference in relative size between auctions and negotiations is not significant in the Boone and Mulherin (2007) sample in contrast with a $p$-value of .05 between the relative size means in our sample.

Panel B provides summary statistics about deal characteristics. Variable definitions are in Appendix D. The toehold dummy indicates acquirers that hold some ownership in the target before the deal announcement date. Cash and toehold dummies are computed using information from the SDC database and are known to be potential determinants of the bid premium [see Table 5 in Betton et al. (2008)]. Since information about deal-initiation has been collected from the SEC filings, the target-initiated dummy is not available for the full SDC sample.

All cash deals represent $22.33 \%$ of the SEC Filings sample. This figure is not far from the frequency of cash payment in the SDC sample (20.32\%). All cash deals are more frequent for auctions than for negotiations. Boone and Mulherin (2007) report also significantly more frequent cash acquisition for auctions than for negotiations in their sample.

Targets initiate $42.32 \%$ of the transactions in the SEC Filings sample. There is, moreover, a large (and significant) difference between auctions and negotiations with respect 
to deal initiation; target initiate $60.66 \%$ of the deals that involve auctions but only $22.73 \%$ of negotiated deals. This is consistent with initiating bidders attempting to avoid competition and initiating targets seeking to stimulate it. It strongly suggests that the choice of a selling procedure is endogenous and cannot be naively used as an exogenous explanatory variable. Note finally that toehold acquisition is rare, as previously documented in the literature. Betton et al. (forthcoming) report a short-term toehold frequency - defined as target shares acquired in the six months prior to the offer - of only $3 \%$ in a sample of 10,806 control contests between 1973 and 2002. The longer-term toehold frequency reported by these authors is, however, $13 \%$, which is significantly higher than in our sample.

Panels C and D provide information on targets and acquirers. Servaes (1991) argues that acquirer and target Tobin's q's are determinants of takeovers gains but Masulis et al. (2007) do not find a connection between acquirer CARs and acquirer Tobin's $q$. Betton et al. (2008) show that target book-to-market ratio (a variable closely related to Tobin's $q$ ) is a significant determinant of the offer premium. There might be some underlying mechanism responsible for a relation between target Tobin's $q$ and the selling procedure: good targets (high Tobin's $q$ ) being more likely to enter negotiations while targets with low growth opportunities (low Tobin's $q$ ) being more likely to resort to auctions.

Panel $\mathrm{C}$ shows that targets $q$ 's are not significantly different between auctioned and negotiated deals in our sample. The ratio of acquirer to target Tobin's $q$ is, on average, 1.23, but the acquirer to target $q$ ratio is not significantly different between auctioned and negotiated deals.

The run-up in the target stock price before the announcement is a known determinant of the offer premium (see Schwert, 1996). The average run-up is $4.75 \%$ in our SEC Filings sample. This is less than the $6.84 \%$ reported in Betton et al. (forthcoming) for a sample of 9,418 bids during the period 1973-2002. Those authors, however, look at the run-up from 
day -41 to day -2 relative to the announcement date while we use day -39 to day -11 . The last days before the announcement date may explain the difference, since there is undoubtedly leakage in some cases. There is no significant difference in run-up between auctions and negotiations.

Hansen (2001) argues that competitive information is one of the determinants of the selling procedure choice (in particular, targets are willing to limit the number of bidders when sensitive competitive information may be revealed during the selling process). We use target intangibles (these include R\&D investments, patents, etc) scaled by total assets as a proxy for the presence of sensitive information. No significant difference emerges between auctions and negotiations. The high average percentage of target intangibles in our SEC Filings sample (10\% of total assets) is, however, consistent with a high proportion of deals in $\mathrm{R} \& \mathrm{D}$ intensive industries (28.6\% compared to $12.89 \%$ in the full SDC sample). Note also that the proportions of targets from $R \& D$ intensive industries, regulated industries and states with strong takeover impediments are comparable between auctions and negotiations.

Betton et al. (2008) emphasize that the selling procedure might depend on the complexity of the target (auctions being more suited to simple and standardized target). We proxy the complexity of targets activities with the sales concentration ratio (using the Compustat Segment database) which declines with the number and variety of the firm activities and hence is a negative indicator of complexity. No significant difference appears between auctions and negotiations, however.

We report also the average and median target debt ratio for the different samples because this ratio will be used to proxy for target shareholders' eagerness to sell. Approximately one third of targets' total assets are financed by debt. This proportion is remarkably stable across the different samples. 
Masulis et al. (2007) investigate the relations between corporate governance variables and acquirer returns. The relation between anti-takeover devices, one of the components of the GIM index, and the offer premium is investigated in Betton et al. (2008). In our SEC Filings sample, the average acquirer GIM index is 9.49 , very close to the 9.45 reported in Masulis et al. (2007). Auctions and negotiations appear to differ for this indicator: acquirers display higher GIM indexes in auctions than in negotiations. Hence, management teams making more competitive acquisitions appear to be less exposed to the shareholder pressure.

Moeller et al. (2007) study the interaction between the mode of payment, acquirer returns and diversity of opinions about the acquirer's value. The standard deviation of long term earnings per share growth forecasts across financial analysts, one of the two proxies used by the authors to capture the diversity of opinions, is not significantly different between auctions and negotiations in our sample. Its average value in our SEC Filings sample, 3.34, is lower than the 5.08 average value reported by Moeller et al. (2007). The average size of acquirers in their sample of 1,533 transactions (period 1980-2002) is $\$ 5.7$ billion, smaller than the $\$ 14.09$ billion average size in our SEC Filings sample. This difference in size probably explains the difference in the diversity of opinions (smaller firms are presumably more opaque).

\subsection{Bid premium}

Our dependent variable is the bid premium in percentage, defined as the share price offered by the winning bidder deflated by the price of the target four weeks prior to the announcement date.

The bid premium has several advantages (see Eckbo, forthcoming): (i) our main theoretical prediction is about the bid premium (see Section 2.2), (ii) bid premiums are not contaminated by investor revisions of the acquirer's value; e.g., due to a signal conveyed by the mode of payment (Travlos, 1987), due the exercise of real options (Hackbarth and 
Morellec, 2008) or due a revision in the perception of the acquirer's acquisition strategy (Malatesta and Thompson, 1985), (iii) bid premiums are less prone to be affected by rumors (the target short-term run-up is included in the premium) and (iv) the bid premium is not affected by the probability of deal completion [on the relation between expected bidder gains, the probability of deal completion and observed CARs, see, e.g., Betton and Eckbo (2000).]

Table 4 reports that the average bid premium is $44.33 \%$ in the SEC Filings sample, very close to the $43.12 \%$ in the SDC sample. Betton et al. (2008) find an average bid premium of the same magnitude. Our bid premiums are also very close to those reported by Bates et al. (2006); in their sample of 3,918 transactions (extracted from the SDC database, for the period 1988-2003) the average premium is $50.1 \%$ for deals without toeholds and $39.9 \%$ for deals with toeholds. The authors compute the premium over a 42-day period, somewhat longer the 4-week period that we use. Note finally that we find no significant difference between auctions and negotiations for the bid premium. This is consistent with competition being as strong for negotiated as for auctioned deals.

\section{[Insert Table 4 About Here]}

\subsection{Proxies for ex ante competition and auction costs}

Ex ante competition is, by nature, not observable. In the theoretical analysis introduced in Section 2.2, it is associated with the number of rivals that the initial bidder and target anticipate for a second-stage auction if negotiations fail. It involves perceptions of the negotiating parties. We introduce four proxies for ex ante competition:

$M \& A$ waves. During M\&A waves, competition is intense among bidders to acquire targets. We use the algorithm proposed by Harford (2005) to detect industry M\&A waves, implemented as follows: We extract a large sample of M\&A transactions from the SDC database for the period 1992-2007, focusing on completed transactions involving U.S. targets, with a deal sizes over $\$ 50$ million. There are 7,510 such transactions. Next, we 
assign each transaction to one of the 49 Fama-French industries based on the target's industry. Then, for each industry and for each sub-period (1992-2000 and 2001-2007), we identify the highest 24-month concentration of merger involving firms in that industry. This produces two candidate M\&A waves. Finally, we test whether the candidate M\&A waves are statistically significant waves using a non-parametric test. ${ }^{13}$

This procedure identifies 75 significant industry waves during the period 1992-2007, considerably more than the 35 industry waves reported in Harford (2005) during the period 1981-2000. Among the potential explanations for this difference are (i) the very active M\&A market during 2003-2007, (ii) the shorter total period [eight years in our case against ten in Harford (2005)], which, however, reduces the probability of observing a candidate wave and (iii) inclusion of a more recent period when the SDC database coverage is more extensive, (iv) exclusion of the quiet 1981-1990 era [only 9 out of the 35 waves detected by Harford (2005) are in this earlier period.]

Table 4 presents some summary statistics for the wave dummy. $37.56 \%$ of the deals in the SEC Filings sample are announced within an industry M\&A wave. This is slightly more than the proportion observed for the more comprehensive SDC sample (32.51\%). There is no difference between auctions and negotiations.

Using M\&A waves to proxy for ex ante competition raises the issue of hindsight because it exploits ex-post observations of M\&As in a given industry over a long period (eight years in our case). This is not observable by acquirers and targets during negotiations; hence one could argue M\&A waves cannot represent a valid determinant of the bid premium.

However, the negotiating parties could assess the probability of being in the midst of an industry M\&A wave. In accordance with this notion, we use a second version of the wave dummy, the predicted wave variable, an estimated probability of being in an industry M\&A

\footnotetext{
${ }^{13}$ The non-parametric test of significance is described in Harford (2005). It is based on a numerical simulation of the frequency distribution of M\&As in a given industry under the null hypothesis of no wave.
} 
wave. This probability is estimated from a logit model, where the dependent variable is 1.0 if the industry-month is in a merger wave. We use a set of determinants (taken from Harford $(2005)^{14}$; see Panel E of Appendix D) known to the negotiating parties; all these determinants are measured at the year-end prior to the acquisition announcement.

Table 5 presents the results of the logit estimation. As expected, high market valuation and economic shock ${ }^{15}$ increase the probability of being in an industry M\&A wave (see Rhodes-Kropf and Viswanathan, 2004). Consistent with Harford (2005), the coefficient of the interaction variable between economic shock and tight capital variable ${ }^{16}$ is negative. This suggests that industry M\&A waves are more likely when there are favorable financing conditions.

\section{[Insert Table 5 About Here]}

Table 4 reports also descriptive statistics about the predicted wave variable. They confirm the results obtained with the wave dummy variable. The average probability of being in an industry wave for the SEC Filings sample is comparable to the average probability for the larger $S D C$ sample and there is no significant difference between auctions and negotiations.

Since the predicted wave variable is estimated from a logit model, its use later as an independent variable raises the issue of valid inferences with generated regressors. Section 3.4 explains our econometric approach to resolve this problem.

Deal Frequency. The wave variables introduced so far do not provide information on the intensity of the M\&A wave. A waves may be imputed because a few M\&As occur an

\footnotetext{
${ }^{14} \mathrm{We}$ only omit the deregulatory events variable, because the list of events provided in Harford (2005) ends in 1996.

${ }^{15}$ The economic shock index is the first component of a principal component analysis realized on a set of seven variables: the median absolute change of net income over sales, asset turnover, R\&D, capital expenditures, employee growth, ROA and sales growth, computed for each industry-year.

${ }^{16}$ The tight capital variable is a dummy variable taking value one when, for a given industry, the median market-to-book ratio is below its industry-specific time-series median or the C\&I load rate spread is above its time-series median.
} 
industry where they are rare or, conversely, a wave may be due to a very intensive restructuring processes. To capture the wave intensity, we introduce a deal frequency variable, is defined as the number of deals in a given industry during a given period divided by the number of firms in that industry at the beginning of the period.

Deal frequency is estimated by both quarter and semester to examine whether the results are robust periodicity. We also estimate a value-weighted (by deal size) version of the deal frequency variable. It turns out that value-weighting has no effect on the results so we do not report them in the paper.

The use of the contemporaneous deal frequency (by contemporaneous, we mean the deal frequency during the quarter or of the semester when the M\&A transaction is announced) raises two issues. First, if the M\&A transaction is announced at the beginning of the period, it precedes most of the deals used in computing deal frequency; thus, deal frequency might be a poor proxy for ex ante competition perceived by the negotiating parties. Second, contemporaneous deal frequency might be endogenous to the bid premium; i.e., a low bid premium might attract other buyers to the industry. We solve the two issues by lagging deal frequency by one quarter or semester relative to the M\&A transaction announcement date.

Table 4 reports summary statistics about the lagged deal frequency variables. By construction, the semester deal frequency is roughly twice the quarter deal frequency. Deal frequency is economically significant: for the SEC Filings sample, the number of M\&As in the industry during the previous quarter (semester) is on average $4.81 \%(9.01 \%)$ of the firms belonging to that industry. This is comparable to the average deal frequency of $4.65 \%$ $(8.81 \%)$ for the full SDC sample. No significant difference is observed between auctions and negotiations.

Buyout fund activities. Private buyout funds have grown dramatically during the past decade and they could be strong competitors [using a sample of 870 listed U.S. targets during 
the period 2003-2007, Boone and Mulherin (2008b) show that the percentage of winning bids by private equity firms have risen from $6 \%$ to $30 \%$.] So, as an additional proxy for ex ante competition, we use the aggregate investment by U.S. private buyout funds by year, as reported by the SDC VentureXpert database, divided by the aggregate NYSE, AMEX and NASDAQ market value (computed using the CRSP database)..

Even though private buyout funds have grown significantly, Table 4 shows that their aggregate investments remain rather modest relative to total U.S. market value. The proportions are comparable for the SEC Filings and SDC samples but there is a marginally significant difference ( $p$-value of 0.08 ) between auctions and negotiations. Negotiated deals seem to occur when buyout funds are more active. This is consistent either with bidders preferring negotiations when competition is more severe or buyout firms simply being less willing to participate in auctions.

Economic recession. Our last proxy for ex ante competition is economic recession, which is known to inhibit M\&A activity. A recent and typical example involve the so-called "friendly merger wave" of the nineties that vanished with the 2001 recession. An underlying cause might be tightening financing conditions during recessions (see, e.g., Harford, 2005; Betton et al., 2008), which cuts the number of potential buyers and reduces competition. The NBER identifies one economic recession during our 1994-2006 sample period, from March 2001 to November 2001. Table 4 reports that $5.60 \%$ of the SDC sample and $4.91 \%$ of the SEC Filings sample occurred during this recession. No significant difference appears to exist between auctions and negotiations.

Our four proxies for ex ante competition are aimed at capturing the same latent factor. If valid, they should be highly correlated. Panel A of Table 6 presents the correlation coefficients matrix between the ex ante competition proxies for the sub-sample of negotiations. Statistical significance of the correlation coefficients is assessed using a 
classical student test. The statistical significance of the correlation coefficient between the deal frequency variables is not reported because the two variables overlap by one quarter As expected, the wave dummy and the predicted wave variable are significantly correlated to each other and to the lagged deal frequency (by quarter or by semester). Private buyout fund activity is correlated with predicted industry waves and more marginally (at the $10 \%$ level) with lagged deal frequency by semester. Correlations between the recession dummy and the wave variables are negative and significant, as expected. It is also negatively correlated and marginally significant (at the $10 \%$ level) with lagged deal frequency by quarter. However, the recession dummy is not significantly correlated with buyout activity.

\section{[Insert Table 6 About Here]}

In Section 2.2, the private component of auction costs for the target shareholders is mainly defined as the eagerness to sell. Organizing an auction takes time and when target shareholders are under pressure to sell (for whatever reason), they will be more willing to accept the first stage initial acquirer's offer. The eagerness to sell is, however, not observable per se. We use the target debt ratio as a proxy. Our intuition is simply that longer negotiations and sale periods are costly when the target leverage is high. Not only do interest expenses go on during this period but capital reimbursement outflows can put a lot of pressure on targets (especially for fast growing firms). Alternatively, one might argue that the debt ratio could proxy instead for a target's poor financial health. We explore this possibility in Panel B of Table 6 where we report correlations between the target's debt ratio, Tobin's $q$, market to book and return on assets. The target's debt ratio is positively and significantly correlated with its market to book ratio and its return on assets in our sample of negotiated deals. This shows that the target's debt ratio does not act here as a proxy of poor financial health. 


\subsection{Econometric method}

Two econometric issues, endogeneity and generated regressors, can possibly influence the estimated relation between ex ante competition and bid premiums.

\subsubsection{Endogenous sample selection}

Targets might voluntarily avoid one-on-one negotiations. This is suggested by Panel B of Table 3, which reports that only $22.73 \%$ of the negotiated deals are initiated by the target. Consequently, our negotiation sample cannot be considered a random sub-sample of the $S E C$ Filings sample; there is endogenous sample selection. We follow Li and Prabhala (2007) and adopt Heckman's (1979) two-stage procedure for adjusting estimates and Greene (2008, pp. 886-887) for standard-error computations. In the first stage, the probability of being included in a sub-sample (the Negotiation sub-sample in our case) is estimated using a probit model fit with the SEC Filings sample. The dependent variable is a dummy indicating one-on-one negotiations. The independent variables are mostly analogous to those in Table 12 in Boone and Mulherin (2008a). More specifically, we use target intangibles, relative deal size, acquirer size, stock payment, target-initiated deal, industry count (the number of firms in the target's Fama-French industry with a market value greater than the market value of the target in the year prior to the merger) and a strong anti-takeover state (a dummy indicating targets that are incorporated in states with strong takeover impediments). We add to this list the target Tobin's $q$ ratio, R\&D intensive industry and target sales concentration (see Section 3.1 for justifications of these additions). Variable definitions are in Appendix D.

Let $w_{i}$ denote the vector of control variables for deal $i$ and $\hat{\gamma}$ the vector of coefficient estimates obtained by maximum likelihood. For each transaction in the Negotiation subsample, the Heckman's Lambda is $\hat{\lambda}_{i}=\phi\left(w_{i}^{\prime} \hat{\gamma}\right) / \Phi\left(w_{i}^{\prime} \hat{\gamma}\right)$., where $\phi$ and $\Phi$ denote the Gaussian probability density function and the Gaussian cumulative density function, with mean zero and unit variance, respectively. In the second stage, when regressing the bid 
premium on proxies for ex ante competition (plus other variables) for the Negotiation subsample, Heckman's Lambda is added as an additional regressor.

Table 7 reports the estimation of the first-stage probit model. Non-cash (stock) payment significantly increases the probability of negotiations. Target initiation has the opposite effect, which is consistent with the univariate evidence, reported in Panel B of Table 3, that target-initiators prefer auctions to negotiations. Industry count reduces the probability of negotiations but is only marginally significant ( $p$-value of 0.10 ). The other variables are not statistically significant.

\section{[Insert Table 7 About Here]}

\subsubsection{Generated regressors}

The predicted wave variable, one of our proxies for ex ante competition, is a generated regressor. To circumvent any potential problem, we adopt the approach advocated in Greene (2008, p. 509), which is based on the asymptotic distribution of the two-stage maximum likelihood estimator derived in Murphy and Topel (1985). In our case, the first stage estimates the predicted wave variable with a logit model. The second stage is an OLS linear regression of the bid premium on the predicted wave and a set of other control variables (including Heckman's Lambda when working with the Negotiation sub-sample). Under the assumption of normality of the residuals of the second-stage linear model, the OLS estimator is the maximum likelihood (see Greene, 2008, p. 518). Murphy and Topel (1985) provide the general expression for the asymptotic covariance matrix of the second-stage maximum likelihood estimator:

$$
V_{2}^{*}=\frac{1}{n}\left[V_{2}+V_{2}\left(C V_{1} C^{\prime}-R V_{1} C^{\prime}-C V_{1} R^{\prime \prime}\right) V_{2}\right]
$$

where $n$ is the number of observations, $V_{2}$ is the asymptotic covariance matrix of the second stage estimator (linear regression in our case), $V_{1}$ is the asymptotic covariance matrix of the 
first-stage estimator (the logit model in our case), and the matrices $C$ and $R$ are obtained using the following relations:

$$
\begin{gathered}
C=E\left[\frac{1}{n}\left(\frac{\partial \ln L_{2}}{\partial \theta_{2}}\right)\right]\left(\frac{\partial \ln L_{2}}{\partial \theta_{1}{ }^{\prime}}\right), \\
R=E\left[\frac{1}{n}\left(\frac{\partial \ln L_{2}}{\partial \theta_{2}}\right)\right]\left(\frac{\partial \ln L_{1}}{\partial \theta_{1}{ }^{\prime}}\right),
\end{gathered}
$$

where $\ln L_{1}$ is the log-likelihood of the first-stage model, $\theta_{1}$ is the vector of coefficients of the first-stage model, $\ln L_{2}$ is the log-likelihood of the second-stage model and $\theta_{2}$ is the vector of coefficients of the second-stage model. The matrices $V_{1}$ and $V_{2}$ are estimated using the BHHH estimator (Berndt et al., 1974). The matrices $R$ and $C$ are estimated using the corresponding sample averages, computed at the estimated values of the coefficients vectors. The main diagonal of the matrix $V_{2}^{*}$ provides the variances of the coefficients estimated at the second stage, adjusted for the presence of a generated regressor.

To apply the Murphy and Topel (1985), we must assume normality for the residuals from the linear regression estimated at the second stage. This is required for OLS to be maximum likelihood (in Section 4, we check the impact of the normality assumption using bootstrap.)

\subsection{Results}

Table 8 reports the effects of several ex ante competition proxies for negotiations and the target debt ratio (our proxy for auction costs) on the bid premium. The bid premium is the dependent variable in all specifications. The columns have different proxies for ex ante competition: (1) wave dummy, (2) predicted wave, (3) deal frequency previous quarter, (4) deal frequency previous semester, (5) buyout fund activities and (6) NBER recession dummy. Each specification includes the target debt ratio and the following control variables: cash, toehold, target run-up, target size, target Tobin's $q$, acquirer idiosyncratic risk, acquirer to 
target $q$ ratio, acquirer GIM index, standard deviation across analysts' forecasts of the acquirer's long term earnings growth. Variable definitions are in Appendix D.

\section{[Insert Table 8 About Here]}

The coefficients for five proxies of ex ante competition out of six are at least marginally significant with the expected sign. Deal frequencies lagged a quarter and a semester and buyout activities are strongly significant while wave and NBER recession have $p$-values of 0.09 and 0.10 respectively. Even the least significant variable, predicted wave, has the right sign and a $p$-value of 0.15 . We note also that in all specification, the target debt ratio has a negative and significant coefficient. The overall picture that emerges is as follows. The signs of all proxies of ex ante competition are consistent with Proposition 1 of Section 2 (ex ante competition has a positive impact on the bid premium). Ex ante competition proxies are economically significant. An increase in the deal frequency during the previous quarter by $10 \%$ leads to an increase in the bid premium by $13.6 \%$ on average. Bid premiums are, on average, $7.5 \%$ higher during M\&A waves. During recessions bid premium are reduced by $15 \%$ on average. Targets that negotiate under the pressure of their debt agree to accept a lower premium: the higher the auction costs perceived by the seller, the lower the premium. This is consistent with Proposition 2 of Section 2. The coefficient of the Heckman's lambda is always negative but never statistically significant. Endogenous sample selection seems not to be a major issue for our sample of negotiations.

Some of the control variables are interesting. The relation between target run-up and the bid premium is positive and significant in four specifications out of six. This is consistent with results previously reported in the literature (see, Schwert, 1996; Betton et al., 2000). The bid premium decreases with target size [a result also reported in Betton et al. (2008)] and increases with target Tobin's $q$ (shareholders of more valuable firms obtain higher premiums) 
and with acquirer idiosyncratic risk [which is consistent with the arguments and empirical evidence in Moeller et al. (2007).]

\section{Robustness checks and additional evidence}

This section reports three robustness checks: (1) expanding the set of control variables, (2) testing the normality of residuals in regressions where the predicted M\&A wave is the proxy for ex ante competition (3) and testing whether our proxies of ex ante competition are correlated with the gains that accrue to the merging parties; (to ascertain whether the positive impact of our proxies on the bid premium could arise from their relation to the wealth creation of the merger rather than to the pressure of competition among potential bidders).

Finally, in an effort to explain why our results contrast with previous findings, we apply the same methods to a broader sample, SEC filings, which includes both negotiations and auctions.

\subsection{Additional control variables}

To check for possible missing variables, we added the following constructs:

- The dormant period, the time (in months) since a previous acquisition announcement in the industry of the target. Song and Walkling (2000) use the dormant period to measure the degree of surprise. Since most of our ex ante competition proxies are based on industry takeover activity, the dormant period might be correlated with them and have even more power. Moreover, the dormant period might relate to later bid premiums because an M\&A deal could lead investors to anticipate others in the same industry; this could induce an upward revision in the prices of industry firms and result in lower bid premiums when a potential target becomes an actual target.

- Acquirer free cash flow. Jensen (1986) argues that acquirers with large free cash-flow are more willing to undertake value-destroying deals to pursue personal objectives. 
- Executive insider ownership, because it reduces agency conflicts between managers and their shareholders. Insiders are presumably reluctant to undertake value-destroying transactions, so they could be less aggressive bidders (Lewellen et al., 1985).

- A proxy for hubris-infected CEOs, who are too confident of their valuations and thus overbid (Roll, 1986). Our proxy for hubris is based on the observed insider trading activities of acquirer CEOs prior to the announcement date.

- The average industry deal CAR during the year prior to the announcement date, to control for industry attractiveness. Perhaps our proxies of ex ante competition are just picking up target industry desirability. Of course, an attractive industry is likely to entice numerous competitive acquirers, so attractiveness and ex ante competition are not mutually exclusive. From a buyer's perspective, a given industry is attractive if acquisitions are wealth-creating. This is the rationale for using the average deal CAR observed for M\&A transaction in the industry of the target during year prior to the announcement date.

These variables are defined in Appendix D. Table 9 follows the same organization as Table 8. Each column corresponds to a given proxy of ex ante competition and the econometric methods are the same as in Table 8. Unfortunately, lack of availability for some of the five new control variables significantly reduces the sample sizes. Our Negotiation subsample is now limited to 129 observations.

The main lessons from Table 9 are as follows. The statistical significance of most proxies is reinforced (despite the sample size reduction) and, most often, the associated coefficients increase. The only exception is the NBER recession variable, for which the coefficient remains negative but becomes insignificant. The inclusion of additional control variables does not weaken the impact of ex ante competition on bid premiums. The target debt ratio coefficient remains uniformly negative but is statistically significant now in only three of the six specifications. Concerning control variables previously present in Table 8 , target size, 
target run-up and acquirer idiosyncratic risk remain significant but target Tobin's $q$ loses its significance. Among the new control variables, the acquirer's management insider ownership is significant with a negative coefficient in specification (1). This is consistent with less agency conflict. The average industry deal CAR prior to the announcement date is not significant; so the previous results seem uncontaminated by industry attractiveness. Lastly, the Heckman's Lambda coefficient keeps its negative sign and becomes marginally significant in one specification out of six. Table 9 brings some support to the idea that, if endogenous sample-selection plays a role, it leads to lower bid premiums for negotiations on average.

[Insert Table 9 About Here]

\subsection{Robustness of the Murphy and Topel (1985) adjustment for non-normality}

The predicted wave variable is a generated regressor from a first-stage logit model (see Section 3.3 and Table 5). In Tables 8 and 9, we use the Murphy and Topel (1985) theorem to adjust the $p$-values reported in column (2). The adjustment procedure is described in Section 3.4.2 and relies on the assumption that residuals in the second-stage regression are Gaussian. Kolmogorov tests of normality reject normality with a high level of confidence ( $p$-value < $0.01)$.

Consequently, we need to check whether the $p$-values reported in Table 8 and 9 are robust to the observed non-normality. Table 10 provides this check. It reports a percentile-t bootstrap based on case-by-case resampling (Efron and Tibshirani, 1993), which is known to converge fast (Horowitz, 2002) and should perform well even in small samples.

Table 10 compares the Murphy and Topel (1985) adjusted $p$-values to percentile-t boostrap $p$-values* when the predicted wave variable is the proxy for ex ante competition. The bootstrap $p$-values are generally similar to the $p$-values from Table 8 . Hence it seems safe to conclude that the overall inferences are sound even though the second-stage 
regression residuals depart from normality. Note that the predicted wave variable now becomes marginally significant with a bootstrap $p$-value of 0.10 .

[Insert Table 10 About Here]

\subsection{Ex ante competition proxies and gains from the trade}

An alternative explanation for the above empirical results might be that our proxies of ex ante competition actually capture the gains (the synergies) of the merger. ${ }^{17}$ To check this possibility, Table 11 replicates the analyses presented in Table 8 , but this time with the value weighted deal CAR (i.e., weighted bidder and target CARs) as dependent variable. The value weighted deal CAR represents the market's assessment of the gains from the merger. The conclusion that emerges from Table 11 is unambiguous: none of our ex ante competition proxies has a statistically significant relation with the value weighted deal CAR. This rules out one potential source of ambiguity. Note also that the target debt ratio is not significant in any of the specifications presented in Table 11. This reinforces the notion that the target debt ratio does not seem to proxy for (bad) target quality in our sample.

\section{[Insert Table 11 About Here]}

\subsection{Additional evidence}

Boone and Mulherin $(2007,2008 \mathrm{a})$ also present results on the relations among competition, bid premiums, acquirer and target CARs and transaction procedures. They find that competition (measured using information extracted from SEC filings about the private takeover process) does not affect acquirers' CARs and bid premiums. This apparent absence of a relation between the observed number of bidders, bid premiums and acquirer CARs has also been reported in other studies. Betton et al. (2008, Table V), for example, using a sample of 4,889 U.S. control contests for U.S. public targets over the period 1980-2002,

\footnotetext{
${ }^{17}$ We are indebted to Robert Hansen for pointing out this possibility.
} 
report a negative but not statistically significant effect of competition (measured by a dummy variable for takeovers with multiple bidders) on the final offer premium.

This section explores one potential explanation of these previously-reported results, which are in conflict with ours; viz., the samples of M\&A deals in those studies included both negotiated and auctioned deals. Mixing both types of transactions in the same sample might disguise the estimated role of competition. To illustrate this possibility, Table 12 presents results analogous to those in Table 8 but for the SEC filings sample (591 transactions), which contains negotiated and auctioned deals.

\section{[Insert Table 12 About Here]}

A clear picture emerges. Despite a larger sample size, coefficients of the ex ante competition proxies are generally lower in absolute magnitude and less statistically significant in Table 12 than in Table 8. Only the predicted wave proxy exhibits an increase in statistical significance and out of six proxies for ex ante competition, four are now statistically insignificant. This result makes intuitive sense. If acquirers choose negotiations to avoid competition, one would expect them to be particularly vigilant and to bid high enough to deter competition when the likelihood is high that a rival acquirer will appear. Thus, the bid premium should be particularly sensitive to the competitive environment in negotiations. In the case of auctioned transactions, the competition is (formally or informally) organized by the seller (or his advisors). The level of bid premiums is pushed up by this competitive selling procedure and bid premiums appear to be less sensitive to the competitive environment. Consequently, a sample of M\&A transactions that includes both negotiated and auctioned deals does not disentangle the relations among bid premiums, ex post competition and ex ante competition. Finally, it is worth noting (Table 4), that sample average bid premiums are comparable between auctions and negotiations. Evidently, competitive pressure is present during negotiations even though it is not directly observable. 
The target debt ratio coefficient loses its statistical significance in all specification. This result is again consistent with our theoretical predictions. Auction costs impact the target's behavior during negotiations, not when an auction is actually organized (these costs are sunk conditionally on auction organization).

With respect to the control variables included in the regressions of Table 12, the statistically significant toehold coefficient deserves some comment. This is a surprising result because it conflicts with Betton et al. (forthcoming), who use a large sample of 5,825 bids during the period 1973-2002. We note, however, that toehold is not statistically significant in Tables 8 and 9 for negotiations and that toehold might be endogenous to the bid premium. As emphasized in Betton et al. (2008), additional investigation is required to better understand the relations among bid premiums, toeholds and other potentially endogenous deal characteristics.

We conclude this section by mentioning that analogous empirical methods have been applied to a larger sample of 2,398 transactions but with fewer control variables because of availability. The results (not reported for reason of brevity) give no indication that the results in Tables 8 to 12 are sample specific.

\section{Conclusion}

The market for corporate control plays an important role as an external control device for firms. Competition is essential for the efficient allocation of management teams among firms. However, based on previous evidence in the financial literature, observed competition among acquirers seems to be rather low; the vast majority of deals have only a single bidder. Yet there is indirect evidence of competition; most of the gains in acquisitions accrue to the target. These two facts deserve to be reconciled. This paper has emphasized the role of ex ante competition, which is not easily observable. Even if competition seems largely absent ex-post, the existence of potential competitors propels bidders toward more competitive 
actions. To capture this idea, we model a two-stage takeover process. The first stage is a one-on-one negotiation with the target, conducted under the threat of an auction. If negotiations fail, either a takeover battle among rivals takes place, or an auction is organized by the target. Our theory predicts that higher potential competition perceived by the negotiating parties (ex ante competition) draws forth higher first stage bids.

Next, we turn to an empirical test of this prediction. Our results are mainly based on a hand collected dataset of 591 M\&A transactions during 1994-2006. The merger background sections of SEC 14A and S-4 filings for mergers and 14D filings for tender offers allows us to isolate a one-on-one negotiations sub-sample that is used to test our theoretical predictions. We employ several alternative proxies of ex ante competition: M\&A waves, deal frequency in the industry, private buyout funds activities and NBER recessions. Our econometric methods control for endogenous sample selection (the results imply that the type of procedure - negotiation versus auction - is chosen by the deal initiator) and generated regressors. The results are consistent with the initial intuition: ex ante competition significantly increases the bid premium for negotiated transactions.

The results also shed some light on puzzling features of the M\&A market. Why do targets' shareholders so frequently accept negotiated deals, if they would be better off with more competitive bidders? Effective ex ante competition can be the explanation. Let us finally mention that our results bear some policy implications. Because auction costs impair the role of ex ante competition, a channel for the regulator to improve the effectiveness of the market for corporate control as an external corporate governance control device is to lower these costs. For example, a legal framework for organizing sales of firms by auctions could bring interesting innovations. 


\section{Appendix A: Expected seller revenue in a second price auction with $\mathbf{N}$ risk neutral symmetric bidders and private values}

Denote by $v$ a bidder's valuation. The expected seller revenue is the expected secondhighest valuation since the highest bidder in a second price auction pays the second highest bid, (which is the second highest valuation when all bidders bid their valuations.) Given a uniform distribution for $v$, the cumulative density function of valuations is $v$. Valuations being independent, the probability that the $N$ bidders valuation will be below $v$ is $F(v)=v^{N}$. To derive the cumulative density function of the second highest valuation (denoted $F_{(2)}(v)$ ), we note that the second highest valuation will be below $v$ in two cases: either all $N$ valuation are below $v$ (which happens with probability $v^{N}$ ) or one valuation is above $v$ and the remaining $N-\mathbf{1}$ valuations are below $v$ (which happens with probability $(1-v) v^{N-1}$ ). There are $N$ possible occurrences of the latter case. $F_{(2)}(v)$ is therefore equal to $v^{N}+N\left((1-v) v^{N-1}\right)$. The corresponding probability density function (denoted $f_{(2)}(v)$ ) is $N(N-1) v^{N-2}(1-v)$. The expected seller revenue can then be written as $\int_{0}^{1} v f_{(2)}(v) d v$. Solving the integral, the expected seller revenue appears to be $(N-1) /(N+1)$. Note finally that, by revenue equivalence, this result holds quite generally (first-price sealed-bid auctions, second-price sealed-bid auctions, English auctions and Dutch auctions, among others). 


\section{Appendix B: Formal description of the negotiation under the threat of an auction game}

Game description. The player set for our extensive game is $\{$ acquirer, target $\}$. We denote by $\varnothing$ the start of the game, by $b_{1}$ the acquirer's bid during the negotiation phase, and by $b_{2}$ the initial acquirer's bid during the second stage takeover battle. The actions available to the target during the negotiation phase are $\{$ Accept, Refuse $\}$. Terminal histories are $\left(b_{1}\right.$, Accept $)$ and $\left(b_{1}\right.$, Refuse, $\left.b_{2}\right)$. The player function $P($.$) is P(\emptyset)=$ acquirer, $P\left(b_{1}\right)=$ target and $P\left(b_{1}\right.$, Refuse $)=$ acquirer. The game encompasses three sub-games: $\Gamma(\varnothing), \Gamma\left(b_{1}\right)$ and $\Gamma\left(b_{1}\right.$, Refuse).

Players' types and preferences. We assume risk neutrality, so the acquirer's and target's preferences are fully described by their expected payoffs. We denote by $v_{1}$ the target valuation of the initial acquirer (the acquirer starting the negotiation phase) and by $v_{i}$ the valuation of a given acquirer $i . \quad v_{i}$ is a function of the market value of the target (common knowledge) and the synergies the acquirer anticipates. The synergies are private to the acquirer and define its type. ${ }^{18}$ We note that $v_{i}$ is strictly increasing in synergies. Rivals during the second-stage takeover battle are referred to as $i=2 \ldots N$ (there are therefore $N-1$ rivals at this stage). The acquirer and the target have imperfect knowledge of the valuations $v_{i}$ of potential rivals acquirers. We denote the distribution of $v_{i}$ by $F($.$) . Knowledge of F($.$) , which$ responds to the conditions of a cumulative density function, is common to the acquirer and the target. ${ }^{19}$ That amounts to assuming that rival valuations are independent and identically distributed. $v_{(i)}$ denotes the order statistic of $v_{i}$ for the $N-1$ rivals. So, $v_{(1)}$ is the maximum of $\left(v_{2}, \ldots, v_{N}\right)$.

\footnotetext{
${ }^{18}$ This private value framework is more suited to strategic transactions, where the value creation is specific to the complementarities between the acquirer's and the target's activities, than to financial transactions, in which the value creation depends on factors available to any acquirer (see Bulow et al., 1999).

${ }^{19}$ To be more precise, our approach adopts a distributional strategy (see Milgrom, 2004). If $t_{i}$ denotes the acquirer type, we assume that $t_{i}$ follows a $[0,1]$ uniform distribution and that $F($.$) is some invertible function$ defined by $v_{i}=F^{-1}\left(t_{i}\right)$, the inverse of the valuation function.
} 


\section{Appendix C: Ex ante competition, the probability of negotiation failure and initial acquirer and target expected profits.}

Proposition 1 allows us to explore the consequences of an increase in the number of rivals in the second-stage takeover battle on the first stage probability of refusal and the initial acquirer and target expected profits (for ease of discussion, we consider $N-1$ as a continuous variable): $:^{20}$

- At the first stage, the target shareholders' decision problem is to choose between $\left(b_{1}-v_{T}\right)$ and $\left[E\left(p_{2}\right)-v_{T}-c\right]$ [see Eq. (9)] and as shown in Section 2.2.4, both terms are increasing in $N-1$, we conclude that $E\left(\Pi_{1}^{\text {Target }}\right)$ is increasing in $N-1$.

- The probability of the initial acquirer's offer being rejected is $K\left(E\left(p_{2}\right)-b_{1}^{*}\right)$. It's derivative with respect to $N-1$ is $\frac{\partial K\left(E\left(p_{2}\right)-b_{1}^{*}\right)}{\partial\left(E\left(p_{2}\right)-b_{1}^{*}\right)} \times\left[\frac{\partial E\left(p_{2}\right)}{\partial(N-1)}-\frac{\partial b_{1}^{*}}{\partial(N-1)}\right]$. The first term is the probability density function corresponding to $K($.$) and is therefore positive.$ $\frac{\partial E\left(p_{2}\right)}{\partial(N-1)}$ is positive and, $\frac{\partial b_{1}^{*}}{\partial(N-1)}$ is also positive (see again Section 2.2.4). So, $\left[\frac{\partial E\left(p_{2}\right)}{\partial(N-1)}-\frac{\partial b_{1}^{*}}{\partial(N-1)}\right]$ can be either positive or negative depending on the magnitude of the two derivatives. The effect of the number of rivals in the second-stage takeover battle on the probability of the target shareholders rebuffing the initial acquirer's first-stage offer is ambiguous. The expected price in the second stage increases but the equilibrium bid $b_{1}^{*}$ also increases. Which effect dominates depends on $K($.) (the distribution of the second-stage takeover battle costs as perceived by the initial acquirer) and $F($.$) (the$ distribution of the potential rivals' valuations in the second-stage takeover battle, as

\footnotetext{
${ }^{20} \mathrm{~N}-1$ can be dealt with as a discrete variable, as it has been done up to now, but this is somewhat tedious. An alternative approach is to interpret $N-1$ as the ex ante perception of the potential competition strength in the second stage. Our results do not depend on this simplifying assumption.
} 
anticipated by both the initial acquirer and the target's shareholders). This ambiguous relation between ex ante competition and the probability of the negotiations failing may be one of the elements explaining why it is difficult to empirically find a negative relation between the ex post observed number of bidders and the acquirer's abnormal returns (see Boone and Mulherin (2008a)).

- The initial acquirer's expected profit is given by Eq. (12). An increase in $N-1$ lowers both the payoff in the event of successful negotiations $\left(v_{1}-b_{1}^{*}\right)$, and the payoff in the event of a takeover battle ( $\left.E\left(\Pi_{2}^{\text {Acquirer }}\right)\right)$. So, the initial acquirer's expected profit clearly (and intuitively) decreases as the number of rivals in the takeover battle increases. 


\section{Appendix D: Variables definitions}

(COMPUSTAT is the source of variables referred to by item number)

\begin{tabular}{|c|c|}
\hline Variable & Description \\
\hline \multicolumn{2}{|c|}{ Panel A. Dependent Variables } \\
\hline Bid Premium & $\begin{array}{l}\text { The share price offered by the winning bidder to target shareholders } \\
\text { deflated by the price of the target four weeks prior to the announcement } \\
\text { date. }\end{array}$ \\
\hline \multicolumn{2}{|c|}{ Panel B. Ex ante Competition Proxies } \\
\hline Wave & $\begin{array}{l}\text { Dummy variable: } 1 \text { if the deal is announced during a wave detected using } \\
\text { the algorithm in Harford (2005), } 0 \text { otherwise. }\end{array}$ \\
\hline Predicted Wave & $\begin{array}{l}\text { Output of a logit model where the dependent variable is the wave dummy } \\
\text { variable. Table } 5 \text { reports on estimation of the logit model. The } \\
\text { explanatory are defined in Panel E here below. }\end{array}$ \\
\hline $\begin{array}{l}\text { Deal Frequency } \\
\text { Previous Quarter }\end{array}$ & $\begin{array}{l}\text { The number of deals announced in the target industry during the previous } \\
\text { quarter divided by the number of firms in that industry at the beginning of } \\
\text { the previous quarter. }\end{array}$ \\
\hline $\begin{array}{l}\text { Deal Frequency } \\
\text { Previous Semester }\end{array}$ & $\begin{array}{l}\text { The number of deals announced in the target industry during the previous } \\
\text { semester divided by the number of firms in that industry at the beginning } \\
\text { of the previous semester. }\end{array}$ \\
\hline Buyout Activities & $\begin{array}{l}\text { The ratio of aggregate buyout funds investments in the U.S. to aggregate } \\
\text { NYSE, AMEX and NASDAQ market value during the year of the } \\
\text { transaction announcement date. }\end{array}$ \\
\hline NBER Recession & $\begin{array}{l}\text { Dummy variable: } 1 \text { if the transaction occurred during a recession period } \\
\text { (between March } 2001 \text { and November 2001), } 0 \text { otherwise. }\end{array}$ \\
\hline \multicolumn{2}{|c|}{ Panel C. Main control variables } \\
\hline \multicolumn{2}{|l|}{ Firm Characteristics } \\
\hline Size & $\begin{array}{l}\text { Market value of equity (number of shares outstanding multiplied by the } \\
\text { stock price) at day }-40 \text { relative to the announcement date in billions of } \\
\text { dollars. The regressions use the natural log of this variable. }\end{array}$ \\
\hline Relative Size & Ratio of target size to acquirer size. \\
\hline Tobin's $q$ Ratio & $\begin{array}{l}\text { Market value of assets over book value of assets: } \\
\text { (item6 - item60 + item } 25 * \text { item199) / item6. }\end{array}$ \\
\hline $\begin{array}{l}\text { Acquirer to Target } q \\
\text { Ratio }\end{array}$ & Tobin's $q$ of the acquirer divided by Tobin's $q$ of the target. \\
\hline Run-up & $\begin{array}{l}\text { Cumulative abnormal returns from day }-39 \text { to day }-11 \text { relative to the deal } \\
\text { announcement date, where the abnormal returns are obtained using the } \\
\text { beta-one model, which subtracts the daily market portfolio return from } \\
\text { the daily return of each company. }\end{array}$ \\
\hline Intangibles & Firm intangibles over total assets: item 33 / item6. \\
\hline Sales Concentration & $\begin{array}{l}\text { The Herfindahl-Hirschman concentration index of the firm's sales (the } \\
\text { sum of squares of sales shares by industry). Sales by industry are obtained } \\
\text { using the COMPUSTAT Segment database. }\end{array}$ \\
\hline Idiosyncratic Risk & $\begin{array}{l}\text { Standard deviation of abnormal returns from day }-200 \text { to day }-40 \text { relative } \\
\text { to the announcement date. Abnormal returns are obtained using the beta- } \\
\text { one model, which subtracts the daily market portfolio return from the }\end{array}$ \\
\hline
\end{tabular}




\begin{tabular}{|c|c|}
\hline & daily return of each company. \\
\hline GIM Index & $\begin{array}{l}\text { The Gompers, Ishii, and Metrick (2003) index constructed using } \\
\text { information from the Investor Responsibility Research Center (IRRC) } \\
\text { database. Higher index levels correspond to more managerial power. }\end{array}$ \\
\hline $\begin{array}{l}\text { St.Dev. of EPS } \\
\text { Forecasts }\end{array}$ & $\begin{array}{l}\text { Standard deviation of long term earnings per share growth forecasts by } \\
\text { financial analysts; data the Thomson Financial I/B/E/S database. }\end{array}$ \\
\hline Debt Ratio & Long term debt plus current liabilities divided by total assets \\
\hline Market to Book & The market value of equity divided by the book value of equity \\
\hline Return on Assets & Operating income before depreciation divided by total assets \\
\hline \multicolumn{2}{|c|}{ Target's Industry Characteristics } \\
\hline R\&D Intensive Industry & $\begin{array}{l}\text { Dummy variable: } 1 \text { if the target belongs to the top seven most } R \& D \\
\text { intensive industries among the } 49 \text { Fama-French industries. Industry R\&D } \\
\text { intensiveness is the average value of the R\&D ratio for industry firms. } \\
\text { The R\&D ratio is R\&D expenses (item } 46 \text { ) by total assets (item6). }\end{array}$ \\
\hline Regulated Industry & $\begin{array}{l}\text { Dummy variable: } 1 \text { if the target belongs to one of the following Fama- } \\
\text { French industries: Utilities, Banks, Insurance and Communication, } 0 \\
\text { otherwise. }\end{array}$ \\
\hline $\begin{array}{l}\text { Strong Antitakeover } \\
\text { State }\end{array}$ & $\begin{array}{l}\text { Dummy variable: } 1 \text { for targets incorporated in states determined by } \\
\text { Bebchuk and Ferrel (2002) to have strong takeover impediments. These } \\
\text { states are Idaho, Indiana, Maryland, Nevada, Ohio, Pennsylvania, South } \\
\text { Dakota, Tennessee, and Wisconsin. }\end{array}$ \\
\hline Industry Count & $\begin{array}{l}\text { Natural log of the number of firms in the same Fama-French industry as } \\
\text { the target with a market value greater than the target in the year prior to } \\
\text { the merger. }\end{array}$ \\
\hline \multicolumn{2}{|l|}{ Deal Characteristics } \\
\hline Cash & Dummy variable: 1 for purely cash-financed deals, 0 otherwise. \\
\hline Stock & Dummy variable: 1 for purely stock-financed deals, 0 otherwise. \\
\hline Toehold & $\begin{array}{l}\text { Percentage of stocks held by the acquirer prior to the announcement date. } \\
\text { Table } 3 \text { has a dummy version of this variable, which has a value of } 1 \text { if } \\
\text { the acquirer holds any shares of the target before the announcement date } \\
\text { and } 0 \text { otherwise. }\end{array}$ \\
\hline Target-initiated & $\begin{array}{l}\text { Dummy variable: } 1 \text { if the deal is initiated by the target, } 0 \text { otherwise; } \\
\text { (collected from the merger background section of the SEC filings.) }\end{array}$ \\
\hline Relative Deal Size & $\begin{array}{l}\text { Deal size, defined by SDC as the total value of the consideration paid by } \\
\text { the acquirer, excluding fees and expenses divided by acquirer size. }\end{array}$ \\
\hline \multicolumn{2}{|c|}{ Panel D. Additional control variables } \\
\hline Dormant Period & $\begin{array}{l}\text { Number of days between the announcement date and the last previous } \\
\text { significant M\&A deal in the industry (4-digit SIC code) of the target (see } \\
\text { Song and Walkling (2000)), based on 16,736 completed M\&A } \\
\text { transactions in the SDC database that satisfied the following criteria: (i) } \\
\text { deal size above } \$ 1 \text { million, (ii) percentage of shares held before } \\
\text { transaction below 50\%, (iii) percentage of shares held after transaction } \\
\text { above 50\% and (iv) U.S. target. }\end{array}$ \\
\hline Free Cash Flow & $\begin{array}{l}\text { Operating income before depreciation (item 13) minus interest expense } \\
\text { (item 15) minus income taxes (item 16) minus capital expenditures (item } \\
\text { 128), scaled by total assets (item 6). }\end{array}$ \\
\hline Insider ownership & $\begin{array}{l}\text { Percentage of acquiring firm's equity owned by the acquirer's top } \\
\text { management as reported in the Compustat ExecuComp database. }\end{array}$ \\
\hline
\end{tabular}




\begin{tabular}{|c|c|}
\hline Hubris-infected CEO & $\begin{array}{l}\text { Dummy variable: } 1 \text { if the following two conditions are met: (i) over the 2- } \\
\text { year period prior to the acquisition announcement date, the acquirer's } \\
\text { CEO increased net purchases (the difference between shares bought and } \\
\text { shares sold by the CEO during a given time period) and (ii) over the 1- } \\
\text { year period following the acquisition announcement date, the acquirer's } \\
\text { CAR is in the bottom quartile of all acquirers' 1-year CARs. Acquirer } \\
\text { CEO insider trading activities are from the Thomson-Reuter Insider } \\
\text { Filings database. CARs are estimated using the beta-one model, which } \\
\text { subtracts the daily market portfolio return from the daily return of each } \\
\text { company. }\end{array}$ \\
\hline $\begin{array}{l}\text { Average Industry Deal } \\
\text { CAR }_{t-1}\end{array}$ & $\begin{array}{l}\text { The arithmetic average CAR for all transactions that occurred during the } \\
\text { year prior to the announcement date in the target's Fama-French industry. } \\
\text { Deal CAR is the average of the acquirer CAR and target CAR weighted } \\
\text { by their respective market value. Market values are estimated } 40 \text { days } \\
\text { before the announcement date. CARs are estimated using the beta-one } \\
\text { model, which subtracts the daily market portfolio return from the daily } \\
\text { return of each company. }\end{array}$ \\
\hline \multicolumn{2}{|c|}{ Panel E. Determinants of Merger Waves } \\
\hline Market-to-Book & Industry median market-to-book ratio \\
\hline 3-Year Return & $\begin{array}{l}\text { Median return in the industry for the three years prior to the } \\
\text { announcement. }\end{array}$ \\
\hline$\sigma(3-$ Year Return) & Intra-industry standard deviation of the 3-year return \\
\hline C\&I Loan Rate Spread & $\begin{array}{l}\text { Difference between the rate charged for commercial and industrial loans } \\
\text { and the Fed funds rate, as reported in the U.S. Federal Reserve Bank's } \\
\text { Survey of Terms of Business Lending. It is used as a proxy for low } \\
\text { capital liquidity. }\end{array}$ \\
\hline Economic Shock Index & $\begin{array}{l}\text { First principal component of seven economic shock variables (the median } \\
\text { absolute change of net income over sales, asset turnover, R\&D, capital } \\
\text { expenditures, employee growth, ROA and sales growth), computed for } \\
\text { each industry-year. }\end{array}$ \\
\hline Tight Capital & $\begin{array}{l}\text { Dummy variable: } 1 \text { when, for a given industry, the median market-to- } \\
\text { book ratio is below its industry-specific time-series median or the C\&I } \\
\text { loan rate spread is above its time-series median, } 0 \text { otherwise. }\end{array}$ \\
\hline
\end{tabular}




\section{References}

Ahern, K., 2009. Bargaining power and industry dependence in mergers. Unpublished working paper. University of Michigan, Ross School of Business.

Andrade, G., Mitchell, M., Stafford, E., 2001. New evidence and perspectives on mergers. Journal of Economic Perspectives 15, 103-210.

Bates, T.W., Lemmon, M.L., Linck, J.S., 2006. Shareholder wealth effects and bid negotiation in free-out deals: Are minority shareholders left out in the cold? Journal of Financial Economics 81, 681-708.

Baumol, W.J., 1982. Contestable markets: An uprising in the theory of industry structure. American Economic Review 72, 1-15.

Bebchuk, L., Ferrell, A., 2002. On takeover law and regulatory competition. Business Lawyer 57, 1047-1068.

Berndt, E., Hall, B., Hall, R., Hausman, J., 1974. Estimation and inference in nonlinear structural models. Annals of Social Measurement 3, 653-665.

Betton, S., Eckbo, B.E., 2000. Toeholds, bid jumps, and expected payoffs in takeovers. Review of Financial Studies 13, 841-882.

Betton, S., Eckbo, B.E., Thorburn, K.S., 2008. Corporate takeovers. In: Eckbo, B.E. (Ed.), Handbook of Corporate Finance, Empirical Corporate Finance. Elsevier, North-Holland, Vol. 2, pp. 291-429.

Betton, S., Eckbo, B.E., Thorburn, K.S., forthcoming. Merger negotiations and the toehold puzzle. Journal of Financial Economics.

Boone, A.L., Mulherin, H.L., 2007. How are firms sold? Journal of Finance 62, 847-875.

Boone, A.L., Mulherin, H.L., 2008a. Do auctions induce a winner's curse? New evidence from the corporate takeover market. Journal of Financial Economics 89, 1-19.

Boone, A.L., Mulherin, H.L., 2008b. Do private equity consortiums impede takeover competition? Unpublished working paper. http://ssrn.com/abstract=1104224.

Bulow, J., Klemperer, P., 1996. Auctions versus negotiations. American Economic Review 86, 180-194.

Bulow, J., Klemperer, P., 2007. When are auctions best? Unpublished working paper. Stanford University, Graduate School of Business Research Paper No. 1973.

Bulow, J., Huang, M., Klemperer, P., 1999. Toeholds and takeovers. Journal of Political Economy 107, 427-454.

Burkart, M., Gromb, D., Panunzi, F., 2000. Agency conflicts in public and negotiated transfers of corporate control. Journal of Finance 55, 647-677.

Dasgupta, S., Hansen, R.G., 2007. Auctions in corporate finance. In: Eckbo, B.E. (Ed.), Handbook of Corporate Finance, Empirical Corporate Finance. Elsevier, North-Holland, Vol. 1, pp. 87-144.

Eckbo, B.E., forthcoming. Bid strategies and takeover premiums: A review. Journal of Corporate Finance.

Efron, B., Tibshirani, R.J., 1993. An Introduction to the Bootstrap. Chapman \& Hall, London.

Fishman, M.J., 1988. A theory of preemptive takeover bidding. RAND Journal of Economics $19,88-101$.

Fishman, M.J., 1989. Pre-emptive bidding and the role of the medium of exchange in acquisitions. Journal of Finance 44, 41-57. 
Gompers, P.A., Ishii, J.L., Metrick, A., 2003. Corporate governance and equity prices. Quarterly Journal of Economics 118, 107-155.

Greene, W.H., 2008. Econometric Analysis (Pearson Prentice Hall).

Grossman, S.J., Hart, O.D., 1980. Takeover bids, the free-rider problem, and the theory of the corporation. Bell Journal of Economics 11, 42-64.

Hackbarth, D., Morellec, E., 2008. Stock returns in mergers and acquisitions. Journal of Finance 63. 213-1252.

Hansen, R.G., 1987. A theory for the choice of exchange medium in mergers and acquisitions. Journal of Business 60, 75-95.

Hansen, R.G., 2001. Auctions of companies. Economic Inquiry 39, 30-43.

Harford, J., 2005. What drives merger waves? Journal of Financial Economics 77, 529-560.

Heckman, J.J., 1979. Sample selection bias as a specification error. Econometrica 47, 153161.

Horowitz, J.L., 2002. The bootstrap. In: Heckman, J.J., Leamer, E.E. (Ed.), Handbook of Econometrics. Elsevier, Saint-Louis.

Jensen, M.C., 1986. Agency costs of free cash flow, corporate finance, and takeovers. American Economic Review 76, 323-329.

Jensen, M.C., Ruback, R.S., 1983. The market for corporate control: The scientific evidence. Journal of Financial Economics 11, 5-50.

Lewellen, W., Loderer, C., Rosenfeld, A., 1985. Merger decisions and executive stock ownership in acquiring firms. Journal of Accounting and Economics 7, 209-231.

Li, K., Prabhala, N.R., 2007. Self-selection models in corporate finance. In: Eckbo, B.E. (Ed.), Handbook of Corporate Finance, Empirical Corporate Finance. Elsevier, NorthHolland Vol. 1, pp. 37-83.

Malatesta, P.H., Thompson, R., 1985. Partially anticipated events: A model of stock price reactions with an application to corporate acquisitions. Journal of Financial Economics $14,237-250$.

Manne, H.G., 1965. Mergers and the market for corporate control. Journal of Political Economy 73, 110-120.

Masulis, R.W., Wang, C., Xie, F., 2007. Corporate governance and acquirer returns. Journal of Finance 62, 1851-1888.

Matthews, S.A., 1995. A technical primer on auction theory I: Independent private values. CMSEMS Discussion Paper No. 1096, Northwestern University.

Milgrom, P.R., 2004. Putting Auction Theory to Work (Cambridge University Press).

Mitchell, M.L., Lehn, K., 1990. Do bad bidders become good targets? Journal of Political Economy 98, 372-398.

Moeller, S.B., Schlingemann, F.P., Stulz, R.M., 2004. Firm size and the gains from acquisitions. Journal of Financial Economics 73, 201-228.

Moeller, S.B., Schlingemann, F.P., Stulz, R.M., 2007. How do diversity of opinion and information asymmetry affect acquirer returns? Review of Financial Studies 20, 20472078.

Murphy, K.M., Topel, R.H. 1985. Estimation and inference in two-step econometric models. Journal of Business and Economic Stastistics 3, 370-379.

Myerson, R.B., 1981. Optimal auction design. Mathematics of Operation Research 6, 58-73. 
Rhodes-Kropf, M., Viswanathan, S., 2004. Market valuation and merger waves. Journal of Finance 59, 2685-2718.

Riley, J.G., Samuelson, W.F., 1981. Optimal auctions. American Economic Review 71, 381392.

Roll, R., 1986. The hubris hypothesis of corporate takeovers. Journal of Business 59, 197216.

Samuelson, W.F., 1984. Bargaining under asymmetric information. Econometrica 52, 9951006.

Schwert, W.G., 1996. Markup pricing in mergers and acquisitions. Journal of Financial Economics 41, 153-192.

Schwert, W.G., 2000. Hostility in takeovers: In the eyes of the beholder? Journal of Finance $55,2599-2640$.

Servaes, H., 1991. Tobin's Q and the gains from takeovers. Journal of Finance 46, 409-419.

Song, M.H., Walkling, R.A., 2000. Abnormal returns to rivals of acquisition targets: A test of the 'acquisition probability hypothesis'. Journal of Financial Economics 55, 143-171.

Travlos, N.G., 1987. Corporate takeover bids, method of payment, and bidding firms' stock returns. Journal of Finance 42, 943-963.

Vickrey, W., 1961. Counterspeculation, auctions and competitive sealed tenders. Journal of Finance 16, 8-37. 
Table 1

The outcomes of the second-stage takeover battle

This table presents the possible outcomes of the second-stage takeover battle. Under the assumptions introduced in Section 2, three outcomes are possible: the rival highest valuation is below the initial acquirer's bid (Case 1); or between the initial acquirer's bid and the initial acquirer's valuation (Case 2 ); or above the initial acquirer's valuation (Case 3). For each case, the outcome price $p_{2}$, the target shareholders profit $\Pi_{2}^{\text {Target }}$, and the probability of occurrence $\varphi_{i}$ are reported.

\begin{tabular}{|c|c|c|c|}
\hline & $\begin{array}{c}\text { Case } 1 \\
\text { Rival highest valuation } \\
\text { below initial acquirer bid } \\
\qquad v_{(l)} \leq b_{1}\end{array}$ & $\begin{array}{c}\text { Case } 2 \\
\text { Rival highest valuation } \\
\text { between initial acquirer bid } \\
\text { and initial acquirer valuation } \\
\qquad b_{1}<v_{(1)} \leq v_{1} \\
\end{array}$ & $\begin{array}{c}\text { Case } 3 \\
\text { Rival highest valuation } \\
\text { above initial acquirer } \\
\text { valuation } \\
v_{(1)}>v_{l} \\
\end{array}$ \\
\hline Price & $p_{2}=b_{1}$ & $p_{2}=\tilde{v}_{(1)}$ & $p_{2}=v_{1}$ \\
\hline Target profit & $\Pi_{2}^{\text {Target }}=b_{1}-v_{T}-c$ & $\Pi_{2}^{\text {Target }}=\tilde{v}_{(1)}-v_{T}-c$ & $\Pi_{2}^{\text {Target }}=" v_{1}-v_{T}-c$ \\
\hline $\begin{array}{l}\text { Initial acquirer's } \\
\text { profit }\end{array}$ & $\Pi_{2}^{\text {Acquirer }}=v_{1}-b_{1}$ & $\Pi_{2}^{\text {Acquirer }}=v_{1}-\tilde{v}_{(1)}$ & $\Pi_{2}^{\text {Acquirer }}=0$ \\
\hline Probability & $\varphi_{1}=F\left(b_{1}\right)^{N-1}$ & $\varphi_{2}=F\left(v_{1}\right)^{N-1}-F\left(b_{1}\right)^{N-1}$ & $\varphi_{3}=1-F\left(v_{1}\right)^{N-1}$ \\
\hline
\end{tabular}


Table 2

Sample distributions by announcement year

$N$ and \% denote, respectively, the number of acquisitions and the percentage of the sample in each year. The $S D C$ sample includes 2,677 acquisitions on SDC that conform to the selection criteria described in Section 3.1. SEC Filings is the sub-sample of transactions with selling procedures identifiable from SEC filings. Auction includes transactions with multiple bidders. Negotiation includes deals with a single buyer.

\begin{tabular}{lcrlrrrrr}
\hline & \multicolumn{2}{c}{ SDC } & \multicolumn{2}{c}{ SEC Filings } & \multicolumn{2}{c}{ Auction } & \multicolumn{2}{c}{ Negotiation } \\
\hline Year & $N$ & \multicolumn{1}{c}{$\%$} & $N$ & \multicolumn{1}{c}{$\%$} & $N$ & $\%$ & $N$ & $\%$ \\
\hline 1994 & 115 & 4.30 & 13 & 2.20 & 9 & 2.95 & 4 & 1.40 \\
1995 & 225 & 8.40 & 43 & 7.28 & 23 & 7.54 & 20 & 6.99 \\
1996 & 236 & 8.82 & 47 & 7.95 & 24 & 7.87 & 23 & 8.04 \\
1997 & 340 & 12.70 & 57 & 9.64 & 30 & 9.84 & 27 & 9.44 \\
1998 & 335 & 12.51 & 87 & 14.72 & 35 & 11.48 & 52 & 18.18 \\
1999 & 322 & 12.03 & 69 & 11.68 & 30 & 9.84 & 39 & 13.64 \\
2000 & 275 & 10.27 & 57 & 9.64 & 31 & 10.16 & 26 & 9.09 \\
2001 & 192 & 7.17 & 31 & 5.25 & 16 & 5.25 & 15 & 5.24 \\
2002 & 103 & 3.85 & 20 & 3.38 & 11 & 3.61 & 9 & 3.15 \\
2003 & 141 & 5.27 & 39 & 6.60 & 22 & 7.21 & 17 & 5.94 \\
2004 & 147 & 5.49 & 45 & 7.61 & 23 & 7.54 & 22 & 7.69 \\
2005 & 129 & 4.82 & 41 & 6.94 & 27 & 8.85 & 14 & 4.90 \\
2006 & 117 & 4.37 & 42 & 7.11 & 24 & 7.87 & 18 & 6.29 \\
Total & 2,677 & 100.00 & 591 & 100.00 & 305 & 100.00 & 286 & 100.00 \\
\hline
\end{tabular}


Table 3

Descriptions of samples

The SDC sample includes 2,677 acquisitions on SDC that conform to the selection criteria described in Section 3.1. SEC Filings is the sub-sample of transactions with selling procedures identifiable from SEC filings. Negotiation includes deals with a single buyer. $N$ denotes the sample size. Variable definitions are in Appendix D. For dummy variables only the mean is reported, which gives the proportion of deals. The final column displays the $p$-value from a test that the means of the Auction and Negotiation samples are equal. Not available (N/A) entries for the SDC sample are due to missing values.

\begin{tabular}{|c|c|c|c|c|c|c|c|c|c|}
\hline \multirow[t]{2}{*}{ Variable } & \multicolumn{2}{|c|}{$\operatorname{SDC}(N=2,677)$} & \multicolumn{2}{|c|}{ SEC Filings $(N=591)$} & \multicolumn{2}{|c|}{ Auction $(N=305)$} & \multicolumn{2}{|c|}{ Negotiation $(N=286)$} & \multirow[t]{2}{*}{$p$-value } \\
\hline & Mean & Median & Mean & Median & Mean & Median & Mean & Median & \\
\hline \multicolumn{10}{|l|}{ Panel A. Firm Size } \\
\hline Target Size (\$ billions) & 1.18 & 0.17 & 1.96 & 0.41 & 1.07 & 0.30 & 2.91 & 0.55 & 0.00 \\
\hline Acquirer Size ( $\$$ billions) & 7.84 & 1.44 & 14.09 & 4.97 & 11.31 & 4.32 & 17.06 & 6.49 & 0.01 \\
\hline Relative Size & $59 \%$ & $15 \%$ & $20 \%$ & $8 \%$ & $18 \%$ & $7 \%$ & $23 \%$ & $11 \%$ & 0.05 \\
\hline \multicolumn{10}{|l|}{ Panel B. Deal Characteristics } \\
\hline Cash & $20.32 \%$ & & $22.33 \%$ & & $28.85 \%$ & & $15.38 \%$ & & 0.00 \\
\hline Toehold & $2.69 \%$ & & $1.86 \%$ & & $1.64 \%$ & & $2.10 \%$ & & 0.68 \\
\hline Target-initiated & N/A & & $42.31 \%$ & & $60.66 \%$ & & $22.73 \%$ & & 0.00 \\
\hline \multicolumn{10}{|c|}{ Panel C. Target Characteristics } \\
\hline Tobin's $q$ Ratio & N/A & N/A & 1.91 & 1.40 & 1.85 & 1.37 & 1.97 & 1.41 & 0.33 \\
\hline Run-up & N/A & N/A & $4.75 \%$ & $3.73 \%$ & $4.84 \%$ & $3.25 \%$ & $4.66 \%$ & $3.97 \%$ & 0.90 \\
\hline Intangibles & N/A & N/A & $9.73 \%$ & $1.43 \%$ & $9.25 \%$ & $1.30 \%$ & $10.23 \%$ & $1.67 \%$ & 0.44 \\
\hline Sales Concentration & N/A & N/A & 0.06 & 0.04 & 0.06 & 0.04 & 0.07 & 0.04 & 0.50 \\
\hline Debt Ratio & 0.33 & 0.30 & 0.35 & 0.32 & 0.32 & 0.31 & 0.36 & 0.34 & 0.95 \\
\hline R\&D Intensive Industry & $12.89 \%$ & & $28.60 \%$ & & $28.85 \%$ & & $28.32 \%$ & & 0.89 \\
\hline Regulated Industry & $25.33 \%$ & & $31.13 \%$ & & $32.46 \%$ & & $29.72 \%$ & & 0.47 \\
\hline Strong Antitakeover State & $15.52 \%$ & & $18.44 \%$ & & $18.03 \%$ & & $18.88 \%$ & & 0.79 \\
\hline \multicolumn{10}{|c|}{ Panel D. Acquirer Characteristics } \\
\hline Idiosyncratic Risk & $\mathrm{N} / \mathrm{A}$ & N/A & 0.021 & 0.018 & 0.020 & 0.017 & 0.021 & 0.019 & 0.29 \\
\hline Acquirer to Target $q$ Ratio & N/A & N/A & 1.23 & 1.05 & 1.20 & 1.05 & 1.27 & 1.05 & 0.29 \\
\hline GIM Index & N/A & N/A & 9.48 & 9.00 & 9.64 & 10.00 & 9.30 & 9.00 & 0.11 \\
\hline St.Dev. of EPS Forecasts & N/A & N/A & 3.34 & 2.44 & 3.23 & 2.31 & 3.46 & 2.52 & 0.39 \\
\hline
\end{tabular}


Table 4

Bid premium and ex-ante competition proxies: Summary statistics

The SDC sample includes 2,677 acquisitions on SDC that conform to the selection criteria described in Section 3.1. SEC Filings is the sub-sample of transactions with selling procedures identifiable from SEC filings. Auction includes transactions with multiple bidders. Negotiation includes deals with a single buyer. $N$ denotes the sample size. Variable definitions are in Appendix D. The final column displays the $p$-value of a test that the means of the Auction and Negotiation samples are equal.

\begin{tabular}{lrrrrrrrr}
\hline \multirow{2}{*}{ Variable } & \multicolumn{2}{c}{ SDC $(N=2,677)$} & \multicolumn{2}{c}{ SEC Filings $(N=591)$} & \multicolumn{2}{c}{ Auction $(N=305)$} & \multicolumn{2}{c}{ Negotiation $(N=286)$} \\
\hline
\end{tabular}


Table 5

Predicted merger waves

A logit model is estimated in order to predict merger waves within the 49 Fama-French industries over the period 1992-2007. The sample size $(N)$ is 8,820 , which is the number of months in the sample times the number of industries. The dependent variable is equal to one if the industry-month is identified as being in a merger wave using Harford's (2005) algorithm. Industry merger waves are determined using a sample of 7,510 completed deals, extracted from the SDC database, which involve U.S. targets and with deal sizes over $\$ 50$ million. The explanatory variables of the logit are measured at the year-end prior to the acquisition announcement. Variable definitions are in Appendix D. The goodness of fit is measured by the likelihood-ratio $(L R)$ statistic with its corresponding $p$-value. \% Correct Prediction denotes the percentage of industry-months correctly classified as being in or out of a wave.

\begin{tabular}{lcc}
\hline \multicolumn{1}{c}{ Variable } & Coefficient & $p$-value \\
\hline Intercept & 2.02 & 0.00 \\
Market-to-Book & 0.04 & 0.02 \\
3-year return & 0.62 & 0.00 \\
$\sigma(3$-year return) & 0.17 & 0.00 \\
C\&I Loan Rate Spread & -6.19 & 0.65 \\
Economic Shock Index & 1.42 & 0.00 \\
Economic Shock Index * Tight Capital & -1.03 & 0.01 \\
& & \\
$L R$ Statistic & 322.10 & 0.00 \\
$\%$ Correct Prediction & $79.34 \%$ & \\
$N$ & 8,820 & \\
\hline
\end{tabular}


Table 6

Correlations

Panel A reports correlations among ex-ante competition proxies. Panel B present correlations among the target's Tobin's $q$, Market to Book ratio, Return on Assets and Debt ratio. Variable definitions are in Appendix D. Statistical significance of the correlation coefficient is assessed by a classical student test. $* * *, * *$ and $*$ denote statistical significance at the $1 \%, 5 \%$, and $10 \%$ level, respectively. The significance of the correlation between Deal Frequency Previous Quarter and Deal Frequency Previous Semester is not reported because the two variables overlap by one quarter.

Panel A. Correlations among Ex-ante Competition Proxies

\begin{tabular}{lcccccc}
\hline & Wave & $\begin{array}{c}\text { Predicted } \\
\text { Wave }\end{array}$ & $\begin{array}{c}\text { Deal } \\
\text { Frequency } \\
\text { Previous } \\
\text { Quarter }\end{array}$ & $\begin{array}{c}\text { Deal } \\
\text { Frequency } \\
\text { Previous } \\
\text { Semester }\end{array}$ & $\begin{array}{c}\text { Buyout } \\
\text { Activities }\end{array}$ & $\begin{array}{c}\text { NBER } \\
\text { Recession }\end{array}$ \\
\hline Wave & 1.00 & & & & & \\
$\begin{array}{l}\text { Predicted Wave } \\
\text { Deal Frequency }\end{array}$ & $0.27 * * *$ & 1.00 & & & & \\
$\begin{array}{l}\text { Previous Quarter } \\
\text { Deal Frequency }\end{array}$ & $0.34 * * *$ & $0.12^{* * *}$ & 1.00 & & & \\
$\begin{array}{l}\text { Previous Semester } \\
\text { Buyout Activities }\end{array}$ & $0.39 * * *$ & $0.26 * * *$ & 0.71 & 1.00 & & \\
NBER Recession & $-0.19^{* * *}$ & $-0.19 * * *$ & $-0.11^{*}$ & -0.02 & -0.09 & 1.00 \\
\hline
\end{tabular}

Panel B. Correlations between Target Debt Ratio and Financial Health Indicators

Tobin's $q \quad \begin{gathered}\text { Market to } \\ \text { Book }\end{gathered} \begin{gathered}\text { Return on } \\ \text { Assets }\end{gathered}$ Debt Ratio

\begin{tabular}{lcccc}
\hline Tobin's $q$ & 1.00 & & & \\
Market to Book & $0.19^{* * *}$ & 1.00 & & \\
Return on Assets & $0.12^{* *}$ & $0.09^{*}$ & 1.00 & \\
Debt Ratio & -0.07 & $0.19^{* * *}$ & $0.15^{* * *}$ & 1.00 \\
\hline
\end{tabular}


Table 7

Probability of negotiation

A probit model is fit to the 591 deals with identifiable selling procedures (negotiations or auctions) from SEC filings. The dependent variable is a dummy that indicates a negotiated deal. Variable definitions are in Appendix D. The probit's goodness of fit is measured by the likelihood-ratio $(L R)$ statistic and its corresponding $p$-value. \% Correct Prediction denotes the percentage of transactions correctly classified as a negotiation or an auction.

\begin{tabular}{lcc}
\hline \multicolumn{1}{c}{ Variable } & Coefficient & $p$-value \\
\hline Intercept & 0.05 & 0.96 \\
Target Tobin's $q$ ratio & -0.01 & 0.81 \\
Target Intangibles & 0.40 & 0.29 \\
Target Sales Concentration & 0.03 & 0.88 \\
Relative Deal Size & 0.08 & 0.59 \\
Acquirer Size & 0.03 & 0.52 \\
Stock & 0.45 & 0.00 \\
Target-Initiated & -1.01 & 0.00 \\
Industry Count & -0.10 & 0.10 \\
R\&D intensive industry & 0.03 & 0.85 \\
Strong Antitakeover State & -0.04 & 0.79 \\
& & \\
$L R$ Statistic & 112.4 & 0.00 \\
$\%$ Correct Prediction & $68.18 \%$ & \\
$N$ & 591 & \\
\hline
\end{tabular}


Table 8

Multivariate analyses

The dependent variable is the Bid Premium in all specifications. Only the proxy for ex ante competition changes from one specification to another. Deal Freq. Q-1 and Deal Freq. S-1 correspond to Deal Frequency Previous Quarter and Previous Semester, respectively. Variable definitions are in Appendix D. All specifications are estimated by ordinary least squares. Heckman's Lambda is the inverse Mills ratio, obtained using the two-stage Heckman (1979) procedure described in Section 3.4. The first-stage estimation of the probability of negotiation is reported in Table 7. Standard-errors are adjusted in the second stage as described in Section 3.4. $p$-values reported in column (2) are adjusted to account for Predicted Wave being a generated regressor (see Section 3.4 for a description of the adjustment procedure). $R^{2}$ and $F$-Statistic denote the r-square and the Fisher statistic for the regression, respectively. $N$ is the number of observations.

Negotiation Sample $(N=286)$

\begin{tabular}{|c|c|c|c|c|c|c|c|c|c|c|c|c|}
\hline \multirow[t]{2}{*}{ Variable } & \multicolumn{2}{|c|}{$\begin{array}{c}(1) \\
\text { Wave }\end{array}$} & \multicolumn{2}{|c|}{$\begin{array}{c}(2) \\
\text { Predicted Wave }\end{array}$} & \multicolumn{2}{|c|}{$\begin{array}{c}(3) \\
\text { Deal Freq. Q-1 }\end{array}$} & \multicolumn{2}{|c|}{$\begin{array}{c}(4) \\
\text { Deal Freq. S-1 }\end{array}$} & \multicolumn{2}{|c|}{$\begin{array}{c}(5) \\
\text { Buyout Activities }\end{array}$} & \multicolumn{2}{|c|}{$\begin{array}{c}(6) \\
\text { NBER Recession }\end{array}$} \\
\hline & Coef. & $p$-value & Coef. & $p$-value & Coef. & $p$-value & Coef. & $p$-value & Coef. & $p$-value & Coef. & $p$-value \\
\hline Ex ante Competition Proxy & 0.08 & 0.09 & 0.42 & 0.15 & 1.36 & 0.05 & 1.11 & 0.02 & 52.75 & 0.00 & -0.15 & 0.10 \\
\hline Target Debt Ratio & -0.17 & 0.04 & -0.15 & 0.08 & -0.15 & 0.06 & -0.14 & 0.08 & -0.14 & 0.08 & -0.15 & 0.06 \\
\hline \multicolumn{13}{|l|}{ Control Variables } \\
\hline Cash & 0.06 & 0.31 & 0.06 & 0.34 & 0.07 & 0.25 & 0.07 & 0.23 & 0.10 & 0.10 & 0.06 & 0.34 \\
\hline Toehold & 0.17 & 0.89 & 0.26 & 0.83 & 0.26 & 0.83 & 0.28 & 0.82 & 0.07 & 0.95 & 0.25 & 0.84 \\
\hline Target Run-up & 0.20 & 0.09 & 0.21 & 0.08 & 0.19 & 0.11 & 0.18 & 0.13 & 0.21 & 0.07 & 0.20 & 0.09 \\
\hline Target Size & -0.07 & 0.00 & -0.06 & 0.00 & -0.07 & 0.00 & -0.07 & 0.00 & -0.06 & 0.00 & -0.06 & 0.00 \\
\hline Target Tobin's $q$ Ratio & 0.04 & 0.01 & 0.04 & 0.01 & 0.05 & 0.00 & 0.05 & 0.00 & 0.04 & 0.01 & 0.04 & 0.01 \\
\hline Acquirer Idiosyncratic Risk & 7.82 & 0.00 & 8.38 & 0.00 & 8.05 & 0.00 & 7.76 & 0.00 & 8.22 & 0.00 & 9.21 & 0.00 \\
\hline Acquirer to Target $q$ Ratio & $-2 \mathrm{E}-2$ & 0.95 & $-4 \mathrm{E}-4$ & 0.99 & $3 \mathrm{E}-3$ & 0.90 & 0.01 & 0.86 & $-3 E-3$ & 0.90 & $-2 \mathrm{E}-3$ & 0.93 \\
\hline Acquirer GIM Index & -0.01 & 0.54 & -0.01 & 0.58 & -0.01 & 0.45 & -0.01 & 0.46 & -0.01 & 0.39 & -0.01 & 0.55 \\
\hline St.Dev. of Acquirer EPS Forecasts & $-1 E-4$ & 0.98 & $-1 \mathrm{E}-3$ & 0.83 & $-2 \mathrm{E}-3$ & 0.80 & $-2 \mathrm{E}-3$ & 0.76 & $-1 E-3$ & 0.91 & $-2 \mathrm{E}-3$ & 0.81 \\
\hline Heckman's Lambda & -0.1 & 0.19 & -0.10 & 0.20 & -0.09 & 0.23 & -0.09 & 0.20 & -0.10 & 0.18 & -0.09 & 0.21 \\
\hline Adjusted- $R^{2}$ & $24.1 \%$ & & $23.9 \%$ & & $24.3 \%$ & & $24.7 \%$ & & $25.9 \%$ & & $24.0 \%$ & \\
\hline$F$-Statistic & 7.22 & 0.00 & 7.14 & 0.00 & 7.31 & 0.00 & 7.45 & 0.00 & 7.94 & 0.00 & 7.19 & 0.00 \\
\hline
\end{tabular}


Table 9

Multivariate analyses with additional control variables

The dependent variable is the Bid Premium in all specifications. Only the proxy for ex ante competition changes from one specification to another. Deal Freq. Q-1 and Deal Freq. S-1 correspond to Deal Frequency Previous Quarter and Previous Semester, respectively. Compared to Table 8, additional control variables are included: Dormant Period, Acquirer Free Cash Flow, Management Ownership, Hubris-Infected CEO and Average Industry Deal CAR tVariable definitions are in Appendix D. The econometric methods for the different specifications are the same as in Table 8 . $R^{2}$ and $F$-Statistic denote the rsquare and the Fisher statistic of the regression, respectively. $N$ is the number of observations.

Negotiation Sample $(\mathrm{N}=129)$

\begin{tabular}{|c|c|c|c|c|c|c|c|c|c|c|c|c|}
\hline \multirow[t]{2}{*}{ Variable } & \multicolumn{2}{|c|}{$\begin{array}{c}(1) \\
\text { Wave }\end{array}$} & \multicolumn{2}{|c|}{$\begin{array}{c}(2) \\
\text { Predicted Wave }\end{array}$} & \multicolumn{2}{|c|}{$\begin{array}{c}(3) \\
\text { Deal Freq. Q-1 }\end{array}$} & \multicolumn{2}{|c|}{$\begin{array}{c}(4) \\
\text { Deal Freq. S-1 }\end{array}$} & \multicolumn{2}{|c|}{$\begin{array}{c}\text { (5) } \\
\text { Buyout Activities }\end{array}$} & \multicolumn{2}{|c|}{$\begin{array}{c}(6) \\
\text { NBER Recession }\end{array}$} \\
\hline & Coef. & $p$-value & Coef. & $p$-value & Coef. & $p$-value & Coef. & $p$-value & Coef. & $p$-value & Coef. & $p$-value \\
\hline Ex ante Competition Proxy & 0.17 & 0.02 & 0.94 & 0.02 & 3.65 & 0.00 & 2.15 & 0.00 & 60.80 & 0.01 & -0.08 & 0.64 \\
\hline Target Debt Ratio & -0.26 & 0.05 & -0.20 & 0.13 & -0.23 & 0.08 & -0.21 & 0.10 & -0.17 & 0.19 & -0.18 & 0.18 \\
\hline \multicolumn{13}{|l|}{ Control Variables } \\
\hline Cash & -0.02 & 0.82 & -0.03 & 0.78 & 0.01 & 0.93 & -0.01 & 0.93 & 0.06 & 0.50 & 0.01 & 0.88 \\
\hline Toehold & 1.25 & 0.48 & 2.21 & 0.21 & 1.79 & 0.30 & 1.80 & 0.30 & 2.00 & 0.25 & 1.85 & 0.30 \\
\hline Target Run-up & 0.45 & 0.01 & 0.50 & 0.00 & 0.43 & 0.01 & 0.40 & 0.02 & 0.46 & 0.01 & 0.47 & 0.01 \\
\hline Target Size & -0.10 & 0.00 & -0.09 & 0.00 & -0.10 & 0.00 & -0.10 & 0.00 & -0.08 & 0.00 & -0.08 & 0.00 \\
\hline Target Tobin's $q$ Ratio & 0.01 & 0.67 & 0.01 & 0.59 & 0.02 & 0.36 & 0.02 & 0.38 & 0.01 & 0.58 & 0.01 & 0.61 \\
\hline Acquirer Idiosyncratic Risk & 5.98 & 0.13 & 8.34 & 0.03 & 6.58 & 0.08 & 5.35 & 0.17 & 8.81 & 0.02 & 8.69 & 0.03 \\
\hline Acquirer to Target $q$ Ratio & -0.04 & 0.26 & -0.02 & 0.53 & -0.02 & 0.58 & -0.02 & 0.61 & -0.02 & 0.52 & -0.03 & 0.40 \\
\hline Acquirer GIM Index & $2 \mathrm{E}-3$ & 0.89 & 0.01 & 0.55 & $4 \mathrm{E}-3$ & 0.73 & $2 \mathrm{E}-3$ & 0.88 & $4 \mathrm{E}-3$ & 0.72 & 0.01 & 0.64 \\
\hline St.Dev. of Acquirer EPS Forecasts & $-5 E-3$ & 0.56 & -0.01 & 0.48 & -0.01 & 0.43 & -0.01 & 0.41 & $-4 E-3$ & 0.63 & -0.01 & 0.47 \\
\hline Dormant Period & $-6 \mathrm{E}-5$ & 0.55 & $-6 \mathrm{E}-5$ & 0.55 & $-3 \mathrm{E}-5$ & 0.81 & $-3 \mathrm{E}-5$ & 0.80 & $-1 \mathrm{E}-4$ & 0.32 & $-8 \mathrm{E}-5$ & 0.47 \\
\hline Acquirer Free Cash Flow & -0.26 & 0.59 & -0.33 & 0.49 & -0.33 & 0.49 & -0.20 & 0.67 & -0.34 & 0.48 & -0.29 & 0.55 \\
\hline Insider Ownership & -5.67 & 0.06 & -4.06 & 0.17 & -4.13 & 0.16 & -3.82 & 0.19 & -2.58 & 0.39 & -3.74 & 0.21 \\
\hline Hubris-infected CEO & 0.03 & 0.76 & 0.07 & 0.46 & 0.08 & 0.39 & 0.09 & 0.33 & 0.04 & 0.66 & 0.09 & 0.35 \\
\hline Average Industry Deal CAR $\mathrm{CA}_{\mathrm{t}-1}$ & -0.67 & 0.21 & -0.56 & 0.29 & -0.77 & 0.15 & -0.77 & 0.15 & -0.75 & 0.16 & -0.70 & 0.20 \\
\hline Heckman's Lambda & -0.19 & 0.13 & -0.16 & 0.21 & -0.20 & 0.11 & -0.21 & 0.09 & -0.20 & 0.12 & -0.17 & 0.17 \\
\hline Adjusted- $R^{2}$ & $34.5 \%$ & & $34.4 \%$ & & $36.0 \%$ & & $35.9 \%$ & & $34.6 \%$ & & $31.6 \%$ & \\
\hline$F$-Statistic & 3.44 & 0.00 & 3.43 & 0.00 & 3.67 & 0.00 & 3.66 & 0.00 & 3.46 & 0.00 & 3.02 & 0.00 \\
\hline
\end{tabular}


Table 10

Bootstrap $p$-values with the predicted wave proxy, a generated regressor

This table compares Murphy and Topel (1985) adjusted $p$-values (see Section 3.4) to percentile-t bootstrap $p$-values when the Predicted Wave is the proxy for ex-ante competition. Predicted Wave is a generated regressor from a first-stage logit model (see Section 3.3 and Table 5). Variable definitions are in Appendix D. Coef. and $p$-value are from Table 8 column (2) and are reproduced here to ease comparison; $p$-value* is the corresponding bootstrap values 1,000 generated samples.

\begin{tabular}{lccc}
\hline \multicolumn{1}{c}{ Variable } & \multicolumn{3}{c}{$\begin{array}{c}\text { Negotiation Sample } \\
(N=286)\end{array}$} \\
\hline & Coef. & $p$-value & $p$-value* \\
\cline { 2 - 4 } Predicted Wave & 0.42 & 0.15 & 0.10 \\
Target Debt ratio & -0.15 & 0.08 & 0.01 \\
$\quad$ & & & \\
$\quad$ Control Variables & & & \\
Cash & 0.06 & 0.34 & 0.23 \\
Toehold & 0.26 & 0.83 & 0.69 \\
Target Run-up & 0.21 & 0.08 & 0.10 \\
Target Size & -0.06 & 0.00 & 0.00 \\
Target Tobin's q Ratio & 0.04 & 0.01 & 0.02 \\
Acquirer Idiosyncratic Risk & 8.38 & 0.00 & 0.00 \\
Acquirer to Target q Ratio & $-4 \mathrm{E}-4$ & 0.99 & 0.96 \\
Acquirer GIM Index & -0.01 & 0.58 & 0.32 \\
St.Dev. of Acquirer EPS Forecasts & $-1 \mathrm{E}-3$ & 0.83 & 0.63 \\
Heckman's Lambda & -0.10 & 0.20 & 0.18 \\
\hline
\end{tabular}


Table 11

Ex ante competition proxies and gains from the trade

The dependent variable is the Deal CAR in all specifications. The Deal CAR is the value-weighted sum of the acquirer and the target $C A R s$. The acquirer and the target CARs are obtained using the market model return generating process. The market model coefficients are estimated over a window from day -200 to day -30 with respect to the announcement date. The event window goes from day -5 to day +5 with respect to the announcement date. The market values of the acquirer and the target are obtained using market prices 30 days before the announcement date. Only the proxy for ex ante competition changes from one specification to another. Deal Freq. Q-1 and Deal Freq. S-1 correspond to Deal Frequency Previous Quarter and Previous Semester, respectively. Variable definitions are in Appendix D. All specifications are estimated by ordinary least squares. Heckman's Lambda is the inverse Mills ratio, obtained using the two-stage Heckman (1979) procedure described in Section 3.4. The first-stage estimation of the probability of negotiation is reported in Table 7. Standarderrors are adjusted in the second stage as described in Section 3.4. p-values reported in column (2) are adjusted to account for Predicted Wave being a generated regressor (see Section 3.4 for a description of the adjustment procedure). $R^{2}$ and $F$-Statistic denote the r-square and the Fisher statistic for the regression, respectively. The number of observations is 286 in all specifications.

\begin{tabular}{|c|c|c|c|c|c|c|c|c|c|c|c|c|}
\hline \multirow[t]{2}{*}{ Variable } & \multicolumn{2}{|c|}{$\begin{array}{c}(1) \\
\text { Wave }\end{array}$} & \multicolumn{2}{|c|}{$\begin{array}{c}(2) \\
\text { Predicted Wave } \\
\end{array}$} & \multicolumn{2}{|c|}{$\begin{array}{c}(3) \\
\text { Deal Freq. Q-1 } \\
\end{array}$} & \multicolumn{2}{|c|}{$\begin{array}{c}(4) \\
\text { Deal Freq. S-1 } \\
\end{array}$} & \multicolumn{2}{|c|}{$\begin{array}{c}(5) \\
\text { Buyout Activities } \\
\end{array}$} & \multicolumn{2}{|c|}{$\begin{array}{c}(6) \\
\text { NBER Recession }\end{array}$} \\
\hline & Coef. & $p$-value & Coef. & $p$-value & Coef. & $p$-value & Coef. & $p$-value & Coef. & $p$-value & Coef. & $p$-value \\
\hline Ex ante Competition Proxy & -0.01 & 0.46 & -0.02 & 0.74 & -0.003 & 0.99 & -0.09 & 0.43 & 2.422 & 0.54 & -0.031 & 0.17 \\
\hline Target Debt Ratio & 0.02 & 0.39 & 0.01 & 0.44 & 0.02 & 0.42 & 0.01 & 0.45 & 0.016 & 0.40 & 0.016 & 0.40 \\
\hline \multicolumn{13}{|l|}{ Control Variables } \\
\hline Cash & 0.028 & 0.05 & 0.028 & 0.05 & 0.028 & 0.05 & 0.027 & 0.06 & 0.029 & 0.04 & 0.026 & 0.07 \\
\hline Toehold & -0.018 & 0.95 & -0.020 & 0.95 & -0.012 & 0.97 & -0.026 & 0.93 & -0.012 & 0.97 & 0.018 & 0.95 \\
\hline Target Run-up & -0.002 & 0.96 & -0.003 & 0.92 & -0.003 & 0.91 & 0.000 & 0.99 & -0.004 & 0.90 & -0.007 & 0.80 \\
\hline Target Size & 0.003 & 0.41 & 0.002 & 0.48 & 0.002 & 0.51 & 0.003 & 0.40 & 0.002 & 0.47 & 0.002 & 0.53 \\
\hline Target Tobin's $q$ Ratio & -0.009 & 0.01 & -0.009 & 0.01 & -0.009 & 0.01 & -0.010 & 0.01 & -0.009 & 0.01 & -0.010 & 0.00 \\
\hline Acquirer Idiosyncratic Risk & 0.852 & 0.12 & 0.803 & 0.14 & 0.812 & 0.14 & 0.850 & 0.12 & 0.811 & 0.14 & 1.003 & 0.07 \\
\hline Acquirer to Target $q$ Ratio & -0.003 & 0.67 & -0.003 & 0.65 & -0.003 & 0.64 & -0.003 & 0.60 & -0.003 & 0.62 & -0.003 & 0.59 \\
\hline Acquirer GIM Index & 0.001 & 0.64 & 0.001 & 0.65 & 0.001 & 0.65 & 0.001 & 0.61 & 0.001 & 0.68 & 0.001 & 0.65 \\
\hline St.Dev. of Acquirer EPS Forecasts & -0.001 & 0.55 & -0.001 & 0.61 & -0.001 & 0.60 & -0.001 & 0.63 & -0.001 & 0.61 & -0.001 & 0.56 \\
\hline Heckman's Lambda & 0.014 & 0.42 & 0.013 & 0.43 & 0.013 & 0.44 & 0.013 & 0.43 & 0.013 & 0.45 & 0.013 & 0.44 \\
\hline Adjusted- $R^{2}$ & $4.6 \%$ & & $4.5 \%$ & & $4.4 \%$ & & $4.7 \%$ & & $4.6 \%$ & & $5.1 \%$ & \\
\hline$F$-Statistic & 1.11 & & 1.07 & & 1.06 & & 1.11 & & 1.09 & & 1.22 & \\
\hline
\end{tabular}


Table 12

The bid premium analysis - SEC Filings sample

The SEC Filings sample includes auctions (multiple bidders) and negotiations (single bidder.) The dependent variable is the Bid Premium in all specifications. Only the proxy for ex ante competition changes from one specification to another. Deal Freq. Q-1 and Deal Freq. S-1 correspond to Deal Frequency Previous Quarter and Previous Semester, respectively. Variable definitions are in Appendix D. All specifications are estimated by ordinary least squares. Heckman's Lambda is the inverse Mills ratio, obtained using the two-stage Heckman (1979) procedure described in Section 3.4. The first-stage estimation of the probability of negotiation is reported in Table 7. Standard-errors are adjusted in the second stage as described in Section 3.4. p-values reported in column (2) are adjusted to account for Predicted Wave being a generated regressor (see Section 3.4 for a description of the adjustment procedure). $R^{2}$ and $F$-Statistic denote the r-square and the Fisher statistic for the regression, respectively. $N$ is the number of observations.

SEC Filings Sample $(N=591)$

\begin{tabular}{|c|c|c|c|c|c|c|c|c|c|c|c|c|}
\hline \multirow[t]{2}{*}{ Variable } & \multicolumn{2}{|c|}{$\begin{array}{c}(1) \\
\text { Wave }\end{array}$} & \multicolumn{2}{|c|}{$\begin{array}{c}(2) \\
\text { Predicted Wave }\end{array}$} & \multicolumn{2}{|c|}{$\begin{array}{c}(3) \\
\text { Deal Freq. Q-1 }\end{array}$} & \multicolumn{2}{|c|}{$\begin{array}{c}(4) \\
\text { Deal Freq. S-1 }\end{array}$} & \multicolumn{2}{|c|}{$\begin{array}{c}\text { (5) } \\
\text { Buyout Activities }\end{array}$} & \multicolumn{2}{|c|}{$\begin{array}{c}(6) \\
\text { NBER Recession }\end{array}$} \\
\hline & Coef. & $p$-value & Coef. & $p$-value & Coef. & $p$-value & Coef. & $p$-value & Coef. & $p$-value & Coef. & $p$-value \\
\hline Ex ante competition proxy & 0.03 & 0.30 & 0.36 & 0.06 & 0.54 & 0.30 & 0.56 & 0.11 & 40.99 & 0.00 & -0.09 & 0.16 \\
\hline Target Debt Ratio & 0.06 & 0.33 & 0.08 & 0.20 & 0.07 & 0.26 & 0.07 & 0.25 & -0.07 & 0.24 & 0.06 & 0.27 \\
\hline \multicolumn{13}{|l|}{ Control Variables } \\
\hline Cash & 0.04 & 0.25 & 0.05 & 0.17 & 0.04 & 0.22 & 0.04 & 0.22 & 0.08 & 0.04 & 0.04 & 0.24 \\
\hline Toehold & 3.57 & 0.00 & 3.53 & 0.00 & 3.54 & 0.00 & 3.56 & 0.00 & 3.38 & 0.00 & 3.55 & 0.00 \\
\hline Target Run-up & 0.34 & 0.00 & 0.34 & 0.00 & 0.33 & 0.00 & 0.32 & 0.00 & 0.34 & 0.00 & 0.35 & 0.00 \\
\hline Target Size & -0.06 & 0.00 & -0.06 & 0.00 & -0.06 & 0.00 & -0.07 & 0.00 & -0.06 & 0.00 & -0.06 & 0.00 \\
\hline Target Tobin's $q$ Ratio & 0.03 & 0.01 & 0.03 & 0.02 & 0.03 & 0.01 & 0.03 & 0.00 & 0.03 & 0.01 & 0.03 & 0.01 \\
\hline Acquirer Idiosyncratic Risk & 6.03 & 0.00 & 6.55 & 0.00 & 6.12 & 0.00 & 5.95 & 0.00 & 6.03 & 0.00 & 6.65 & 0.00 \\
\hline Acquirer to Target $q$ Ratio & $-4 \mathrm{E}-3$ & 0.83 & -0.01 & 0.79 & $-2 \mathrm{E}-3$ & 0.91 & $5 \mathrm{E}-4$ & 0.98 & -0.01 & 0.81 & -0.01 & 0.80 \\
\hline Acquirer GIM Index & $-1 E-3$ & 0.83 & $-2 \mathrm{E}-3$ & 0.78 & $-2 \mathrm{E}-3$ & 0.73 & $-2 \mathrm{E}-3$ & 0.73 & $-3 E-3$ & 0.64 & $-1 \mathrm{E}-3$ & 0.81 \\
\hline St.Dev. of Acquirer growth & $-1 E-3$ & 0.75 & $-2 \mathrm{E}-3$ & 0.62 & $-2 \mathrm{E}-3$ & 0.65 & $-2 \mathrm{E}-3$ & 0.64 & $-1 E-3$ & 0.76 & $-2 \mathrm{E}-3$ & 0.65 \\
\hline Adjusted- $R^{2}$ & $21.1 \%$ & & $21.4 \%$ & & $21.1 \%$ & & $21.3 \%$ & & $22.4 \%$ & & $21.2 \%$ & \\
\hline$F$-Statistic & 13.86 & 0.00 & 14.14 & 0.00 & 13.86 & 0.00 & 14.03 & 0.00 & 14.99 & 0.00 & 13.96 & 0.00 \\
\hline
\end{tabular}

